\title{
JUICIO Y VALORACIÓN DE LAS SIETE PRIMERAS SEMANAS DE LA II REPÚBLICA VISTAS POR UN ESCRITOR JESUITA. EL DIARIO DEL PADRE ALBERTO RISCO, SJ (1873-1937)
}

\author{
POR \\ ALFREDO VERDOY HERRANZ \\ Universidad Pontificia de Comillas, Madrid
}

RESUMEN: El jesuita padre Alberto Risco (1873-1937) fue un reconocido autor de textos católicos y cristianos de corte popular y devoto, entre los que podemos destacar Emigración y su muy famoso Compendio de Historia de la Literatura Española. Con el advenimiento de la II República comienza a redactar un diario, en el que sigue con pasión y detalle las siete primeras semanas del nuevo régimen. A pesar de que por temperamento y tradición Risco se muestra más inclinado al fundamentalismo y al tradicionalismo que a los nuevos aíres de la República, nos ofrece en el texto que ahora presentamos una viva, personal e inspirada visión no muy distinta a la de otros escritores y analistas de su tiempo. Como jesuita, se sintió muy afectado por el futuro de la Iglesia y de la Compañía de Jesús. En consecuencia, presta especial atención a los dolorosos sucesos del 11 de mayo de 1931.

PALABRAS CLAVES: Segunda República Española, anticlericalismo, La Compañía de Jesús, Madrid, 11 de mayo de 1931.

\section{JUDGING AND EVALUATING THE FIRST SEVEN WEEKS OF THE SECOND REPUBLIC AS SEEN BY A JESUIT WRITER. THE DIARY OF FATHER ALBERTO RISCO, SJ (1873-1937).}

\begin{abstract}
Father Alberto Risco (1873-1937) was a renowned author of Christian texts of popular and edifying nature, the main ones being his well-known novel Emigración[Emigration] and his Compendio de Historia de la Literatura Española [Compendium of the Spanish Literature History]. In his diary he follows with passion and detail the first seven weeks of the Second Spanish Republic. Fr. Risco, more inclined to fundamentalism and traditionalism rather than to the Republic, gives us a vivid, personal and latent view of the situation along the lines of the writings of analysts and journalists of that time. As Jesuit, his biggest concern was the fate of the Church and of the Society of Jesus. Consequently, he stopped writing on the painful $11^{\text {th }}$ May 1931.
\end{abstract}

KEY WORDS: Second Spanish Republic, anticlericalism, Society of Jesus, Madrid, 11th may 1931

Recibido/Received: 2011-12-10

Aceptado/Accepted: 2012-01-29

La Segunda República no llegó de sopetón. Las autoridades y más concretamente los eclesiásticos esperaban, tras la caída del régimen de Primo de Rivera y los débiles gobiernos de Aznar y Berenguer, que algo muy próximo al cambio de régimen estaba encubándose en los meses previos a abril de 1931. Los jesuitas eran muy conscientes del pésimo porvenir que tenían por delante; imaginaban que una vez más volverían a ser expulsados y que todos sus ministerios espirituales, obras 
apostólicas, instituciones docentes y centros propios de formación quedarían arruinados y casi con toda probabilidad sus propiedades pasarían a ser bienes de la nación, de la nueva nación republicana. No se equivocaron.

Tenemos muchas pruebas del nerviosismo y del susto que entre los jesuitas españoles supuso la proclamación de la Segunda República. Una de ellas es el apasionado y detallado diario que el Padre Alberto Risco (1873-1937) escribió al hilo de los acontecimientos que el nuevo régimen traía consigo. Diario, ciertamente, breve en el tiempo, de apenas siete semanas, y en el que de un modo muy particular escribe y enjuicia el régimen republicano.

Alberto Risco nació en la localidad de Morón de la Rocha (Santiago de Cuba) en 1873 y falleció en la primavera de 1937 en Valladolid. Risco, terminada su formación, se dedicó con entusiasmo y mucho fruto al ministerio de la pluma y a los más variados ministerios apostólicos. Dentro del campo de la prensa católica fue un destacado publicista. Fue colaborador habitual de varias revistas españolas e hispanoamericanas: Razón y Fe. La Semana Católica y La Lectura Dominical y, también fue autor de numerosas obras.

Comenzó su noviciado el año 1890; fue ordenado sacerdote en Tortosa en 1906. Como sacerdote jesuita se dedico a la enseñanza, a la predicación y la publicación de artículos y libros. En sus años de Magisterio, tiempo que los jesuitas una vez terminados sus estudios de filosofía y antes de comenzar los de teología dedican a la enseñanza en sus Colegios, enseñó Gramática y Literatura española entre 1898 y 1903 en el Colegio de San Estanislao del Palo (Málaga) y desde 1909 a 1912 en el de San Calixto de la Paz (Bolivia). Fruto de sus preocupaciones docentes y de sus dotes pedagógicas fue su Compendio de Historia de la Literatura española; una buena síntesis, aunque algo elemental y recortada, de la literatura española y universal; texto que estuvo vigente durante muchos años en los colegios regentados por religiosos y muy especialmente religiosas tanto en España como en América ${ }^{1}$.

Como predicador, su sermón más conocido fue la oración fúnebre que pronuncio en 1916 con motivo del traslado de los restos del almirante Pascual Cervera (1839-1909) al Panteón de marinos ilustres. Años más tarde la editorial Razón y $\mathrm{Fe}$ publicaba una amplia biografía en la que realzaba su comportamiento heroico en la batalla naval de Santiago de Cuba (1898).

Pero donde realmente brilló fue en su faceta de escritor. Su producción literaria, siguiendo la línea inaugurada por el padre Luis Colona (1851-1915) y a medio camino entre la composición de biografías históricas y ejemplares, la redacción de composiciones literarias y la reconstrucción de hechos y singularidades de la historia de España, es demasiado vasta como para comentarla pormenorizadamente. Entre sus títulos más destacados sobresalen los siguientes: Don Juan de Austria, hijo de Felipe IV: Juan sin Tierra. (Memoria histórica), Madrid (1918), una atinada reconstrucción biográfica de don Juan de Austria. A esta deben sumarse pequeñas biografías de personalidades de su tiempo; destacamos dentro de este grupo la del Padre Juan de la Cruz Granero de la Compañía de Jesús, Madrid (1919); la de Don Francisco de Paula Romero y Palomeque, Jerez de la Frontera (1919); El Padre Francisco de Paula Tarín de la Compañía de Jesús: apuntes biográficos de este incansable misionero de los pueblos a quien los pueblos han dado con justicia el título de Apóstol del Sagrado Corazón de Jesús, Madrid 1921. La ya citada del Almirante Cervera, Biografía del Excmo. Sr. Don Pascual Cervera Topete, Almirante de la Marina de Guerra Española: apéndices y documentos, Madrid (1921).

${ }^{1}$ O’Neill, Ch. E y Domínguez, J. Ma 2001 Diccionario histórico de la Compañía de Jesús, tomo IV. Madrid y Roma: Universidad Pontificia Comillas (Madrid) e Institutum Historicum S.I: 3366-3367

Hispania Sacra, LXIV Extra I, enero-junio 2012, 9-46, e-ISSN: 1988-4265, doi: 10.3989/hs.2012.025 
Amén de las citadas anteriormente salieron de su pluma floridas biografías cuyas protagonistas principales fueron damas y señoras de la burguesía católica de su tiempo y de tiempos pasados. Destacamos las siguientes: Ángel y apóstol: recuerdos biográficos de la Srta Doña Asunción de Alvear y Abaurrea, Madrid (1923); Santa Teresa de Jesús, Bilbao (1925); La Condesa Viuda de Armildez de Toledo, Marquesa de la Cañada y de San Martín de la Ascensión. Apuntes biográficos sobre las obras de celo y de piedad cristiana llevadas a cabo en Madrid por la Excma. Sra. D ${ }^{\text {a }}$ María Luisa Daigo y Terry, Madrid (1927); Fray Francisco: narración histórica, Madrid (1933); En las Islas de los Ladrones; el apóstol de las Marianas: Diego Luis de San Vitores, Bilbao (1935) y San Juan Bosco, Madrid (1935). Igualmente fueron abundantes sus composiciones literarias: Tristes y alegres: colección de cuentos morales para todos los aburridos de la sociedad, Madrid (1911); Amor de madre: colección de poesías líricas y dramáticas, Madrid (1913); Los dos amores: narraciones históricas, Madrid (1918); Clavelilla y otros cuentos, Madrid (1929); Sevilla por María. Loa a Personajes Marianos en la Historia de Sevilla para obsequiar a las Juventudes Marianas de la América de raza de iberos, Madrid (1929) y, finalmente y por encima de todas, su novela, Emigración, Madrid (1929). Copiosa fue su reconstrucción, siempre desde el tradicionalismo y las esencias de la España eterna, de hechos, personalidades y singularidades españolas: a su biografía del Almirante Cervera deben añadirse sus trabajos históricos sobre Zumalacárregui en campaña: según los documentos conservados por su secretario de Estado Mayor, don Antonio Zaratiegui, Madrid (1935) y La epopeya del Alcázar de Toledo: relación histórica de los sucesos desde los comienzos del asedio hasta su liberación, 21 de julio a 28 de septiembre de 1936, Burgos 1937

Presentado el autor, presentaremos, brevemente, su diario; el texto que forma parte y constituye el objetivo fundamental de este trabajo.

EL texto es un texto autógrafo, que ocupa la práctica totalidad de un cuaderno de pasta dura; su paginación está sin numerar. Al texto se le han añadido unas cuantas ilustraciones a modo de fotografías, tomadas del diario Ahora, fechadas y colocadas a lo largo de varias jornadas: las del 11 de mayo de 1931: seis fotografías y un recorte procedente de la Revista La Estrella del Mar, órgano oficial de las Congregaciones Marianas de España, de la que Risco era colaborador habitual.

El relato, que no lleva ningún título, comienza el sábado 11 de abril de 1931 y finaliza el 30 de diciembre de ese mismo año. El grueso de este diario lo ocupa su relato del acontecer republicano del sábado 11 de abril al domingo 17 de mayo, fecha en la que Risco a instancias del Padre Medina, Provincial de Toledo, parte para la segura y alejada Loyola en Guipúzcoa. El resto, desde esa fecha hasta el 30 de diciembre, son meros apuntes en los que Risco sigue la actualidad nacional y muy de vez en cuando consigna lo que lee en la prensa nacional y oye en su entorno. Por razones obvias, las anotaciones que Risco escribe en Loyola, muy dependientes de la prensa que por entonces leían los jesuitas que era fundamentalmente El Debate, no nos han parecido sugerentes, razón por la cual no aparecen en la trascripción que ahora presentamos. El diario se guarda en el Archivo que la Compañía de Jesús dirige en su Residencia-Colegio de Alcalá de Henares.

La lectura que de la proclamación y advenimiento de la República hizo el Padre Risco, consignada en lo que llamamos su diario, es la de un monárquico por familia y tradición, la de un sacerdote y religioso, para más señas jesuita, enemigo acérrimo del liberalismo y del comunismo, por vocación $\mathrm{y}$, finalmente, la de un analista social a la antigua usanza para quien todo cambió era criticable y desde luego no aceptable, por profesión y oficio.

A nuestro juicio tres notas caracterizan este diario: su espontaneidad y viveza; su esfuerzo por compilar y acumular datos, posiblemente, para un estudio posterior y, finalmente, su deseo, vano deseo, de dejar para la posteridad su visión y juicio personales sobre el advenimiento de un cambio de 
régimen que, además de poner en la piqueta a su familia religiosa, la Compañía de Jesús, sembraba de infortunio y de pesimismo el porvenir de su querida España. En suma, nos encontramos ante un diario interesado, pretencioso, suficientemente bien informado, muy dependiente de la prensa diaria conservadora y tradicional así como de su propio estado de ánimo. Texto, en suma, rico en detalles y juicios, que lo hacen merecedor de su publicación y, más adelante, de algún estudio posterior. Este diario ha permanecido desconocido hasta el momento presente. Tal vez el pronto fallecimiento de su autor, primavera de 1937, haya podido ser la razón de su desconocimiento.

En la preparación y redacción de esta introducción hemos querido acercarnos a otros "diarios", como el escrito, al hilo de sus artículos periodísticos, por Josep Pla (, 1897-1981) redactados aquellas mismas fechas; también nos hemos servido de dos importantes archivos, todos ellos relacionados con la Iglesia. El Archivo Secreto Vaticano y el Arxiu Vidal i Barraquer, amén de una crecida bibliografía sobre el particular.

De la lectura de estos textos, colegimos que las opiniones de Risco estaban muy en consonancia, desde luego, con los informes que el nuncio Tedeschini (1873-1959) y algunos altos eclesiásticos como los cardenales Pedro Segura (1880-1957) y Francisco de Asís Vidal i Barraquer (1868.1943) remitían a Roma; pero quizás, lo más sorprendente sea la proximidad entre los juicios de un Pla, persona diametralmente opuesta a Risco, y el publicista jesuita.

Todo esto nos ha animado a ofrecer a la comunidad universitaria y a cuantos se quieran acercar estas páginas el texto de Risco. Ante la inmensidad de documentos, libros, folletos, artículos y todo tipo de referencias que sobre los primeros días de la Segunda República se escribieron y se siguen escribiendo, hemos tratado de ajustarnos, para no sentirnos ahogados por tan voluminosa masa documental y bibliográfica, a unas cuantas referencias y citas. Citas y referencias que consideramos indispensables para una mejor lectura del diario de Risco. Somos conscientes y sabedores de algunas de las equivocaciones y yerros que su diario contiene, pero dada su extensión, nos ha parecido mejor no hacer ninguna corrección ni tampoco emitir ningún juicio de valor. Ya habrá tiempo de hacerlo en otra ocasión.

El texto, con todo, puede estructurarse en torno a cuatro etapas: la primera, comprendería los días previos a la proclamación de la República; la segunda, del 14 de abril al 9 de mayo, narra la proclamación de la República; la tercera, 10 y 11 de mayo, se centra en la narración y valoración de los incendios del 11 de mayo y la cuarta y última, el seguimiento más descafeinado y peor informado que desde Loyola siguió haciendo un cada vez más desanimado padre Risco. Por interés histórico y social, presentaremos, únicamente, las tres primeras etapas.

Sábado 11 de abril. " "Son las seis de la tarde; vísperas de elecciones municipales, después de los seis años de dictadura, y de unos meses de Gobierno débil e incapacitado del general Berenguer. ${ }^{3}$

2 Pla, J. 1933. Madrid, el advenimiento de la República: Barcelona. Uutilizamos la edición que hizo Alianza Editorial en 1986. Robinson, R. A. H. 1974. Los orígenes de la España de Franco. Derecha, República y Revolución (1931-1936) Barcelona: Grijalbo. Jato Miranda, D. 1976. Madrid, capital republicana: Madrid. Juliá, S. 1984. Madrid, 1931-1934. De la fiesta popular a la lucha de clases: Madrid: Siglo XXI. Verdoy, A., 1995. Los bienes de los jesuitas. Disolución e incautación de la Compañía de Jesús durante la Segunda República: 53-66 Madrid: Trotta. Ranzato, G., 2006. El eclipse de la democracia. La Guerra Civil española y sus orígenes, 1931-1939: 93-143 Madrid: Siglo XXI.

${ }^{3}$ Puede verse un juicio global sobre el gobierno Berenguer en Carta del Padre Nemesio Otaño, SJ al Cardenal Pacelli, fechado en Madrid a comienzos de abril de 1931. Dicho informe puede encontrarse en Cárcel Ortí, V. 2011. La II República y la Guerra Civil en el Archivo Secreto Vaticano. 1.1. Documentos del año 1931. Febrero-julio: 175-196 Madrid: Biblioteca de Autores Cristianos. Berenguer y Fusté, D.1946. De la dictadura a la República. Crisis del reinado de Alfonso XIII:, Madrid. López de Ochoa, E. 1930. De la Dictadura a la 
La expectación es enorme. Hay una seguridad, a todas luces, falsa, entre la gente de las derechas, seguridad que fomenta criminalmente la apatía y el descuido. ${ }^{4}$ Berenguer ha sido muy dañino para España: da la sensación de que su programa ha sido desatar las izquierdas, concediéndole toda clase de libertades y amordazar a los periódicos y a las personas de orden para que no pudiesen detener la ola de comunismo, ${ }^{5}$ de sectarismo, de antipatriotismo, que durante su gobierno, se ha desbordado en la prensa claramente revolucionaria y disolvente. ${ }^{6}$

Por fin cayó Berenguer y subió el Capitán General de la Armada, mi buen amigo don Juan B. Aznar, ${ }^{7}$ (él que me concedió la cruz del mérito naval) con un gobierno eterogéneo (sic), sin unión de ideales, donde no se ven más que dos hombres de ideas fijas y rectas: don Juan Lacierva ${ }^{8}$ y don Ventosa, ${ }^{9}$ manejado por el muñidor de piruetas y travesuras políticas, el conde de Romanones. ${ }^{10}$ Ventosa es un buen ministro de Hacienda y hombre de orden.

Las elecciones no están preparadas para el triunfo monárquico. ${ }^{11}$ El censo ha sido fabricado, según se dice, en la Casa del Pueblo. ${ }^{12}$ Se ha rectificado durante el veraneo cuando la gente rica, la de las derechas se divertía por el norte de España. En el censo faltan más de 30.000 electores, y todos precisamente de los que habían de votar por los concejales de orden. Yo no estoy en el censo. En las

República: Madrid. Maura, M. 1962. Así cayó Alfonso XIII: Madrid y Así cayó Alfonso XIII. De una dictadura a otra, edición ampliada. 2007, Madrid. Bravo Morata, F. 1973. De la dictadura a la República, 1930-1930: Madrid. Ben.-Ami, Sh. 1990. Los orígenes de la Segunda República: anatomía de una transición: 231-293 Madrid. Gómez Navarro, J. L. 1991. El régimen de Primo de Rivera. Reyes, dictaduras y dictadores: Madrid.

${ }^{4}$ Marina, M. 1936. "La última lección. Comentario editorial". Razón y Fe, FALTA EL NÚMERO: 433451. En este artículo al tiempo que se analizan los resultados de las elecciones de febrero de 1936 se hace una consideración sobre las causas, a las que el autor califica de egoístas y de abúlicas, por las que ni las derechas, ni los católicos ni las gentes de orden votaron como debieron a lo largo de las elecciones del periodo electoral. AZAÑA, M. Causas de la Guerra Civil (1939), en Obras Completas, vol 6, pp 201-205, en la edición de JULIÁ, S., Madrid 2007

${ }^{5}$ La implantación y el crecimiento del comunismo fue una temática que al igual que a sus compañeros jesuitas y al católico español preocupó al padre Risco. Sobre el comunismo Carta del Padre Nemesio Otaño, SJ al Cardenal Pacelli, en CÁRCEL ORTI, V. 2001: 195-196. Jiménez de Asúa, L. 1931 Nueva especie de señorito, en La Libertad, Madrid 7-8-1931; en este artículos los comunistas son calificados por su prepotencia de nuevos señoritos. Comín Colomer, E. 1967. Historia del Partido Comunista de España: Madrid: Editora nacional. Domínguez Niñas, J. L. 1990. "La implantación comunista en el primer bienio republicano". Anales del Instituto de Estudios Madrileños, 28: 495-514. Cruz Martínez, R. 1987. El Partido Comunista de España en la segunda república Madrid. Cruz Martínez, R. 1984. "La organización del PCE (1920-1934)". Estudios de historia social 31 (1984): 223-312.

${ }^{6}$ El padre Risco estaba convencido de que la debilidad del gobierno de Berenguer no sólo no había contenido la disolución de la monarquía sino que la había propiciado; esto mismo parecer defiende en buena parte Zorrilla Bonilla, J. 2010. “Discursos irresponsables y retóticas intransigentes”, en F. Del Río (ed), Palabras como puños. La intransigencia política en la Segunda Republica española: 523-595. Madrid: Taurus.

${ }^{7}$ Bautista Aznar-Cabañas. J.B. (1860-1933)

${ }^{8}$ Cierva Peñafiel, J. de (1864-1938). De la Cierva Peñafiel, J. 1955. Notas de mi vida: Madrid. Sánchez Maurandi. A. 1962. Juan de la Cierva. Estudio biográfico del político murciano Murcia

${ }^{9}$ Ventosa, J. (1879-1953). Fue uno de los fundadores de la Lliga Regionalista; Ministro de Hacienda en 1917, cargo al que será llamado de nuevo por el gobierno Aznar entre febrero y abril de 1931.

${ }^{10}$ Figueroa y Torres, A. 1947. Notas de mi vida, 1912-1931: Madrid: Espasa Calpe. Figueroa y Torres, A. 1947. Y sucedió así. Aportación para la historia: Madrid.

${ }^{11}$ Gil Pecharromán, J. 1994 Conservadores subversivos. La derecha autoritaria alfonsina (1913-1936): 63-67 Madrid: Eudema.

${ }^{12}$ De Luis Martín, F. y Arias González, L. 1997. Las Casas del Pueblo socialista s en España (19001936): estructura social y arquitectónica: Barcelona. 
casas nuestras no están inscritos ni la mitad de los padres que tienen derecho a votar; ${ }^{13}$ se cuenta de casas enteras como la de un general Borbón dónde él ni ninguno de su palacio podrá votar. Y la frase clásica del Gobierno es que se han preparado para mañana unas elecciones rabiosamente legales.

La apatía y la indiferencia más criminal han reinado en la preparación por parte de las derechas. Solo en lo que va de abril se han movido los jóvenes, eso sí, heroicamente. Se ha tenido una junta para recaudar dinero para las elecciones de la derecha y se ha recaudado la irrisoria suma de 22.000 pesetas.

Creo en el resto de España pasa lo mismo. Son las seis de la tarde. Vengo de echar una plática en el asilo de Pallarés: he contado hasta 14 aeroplanos que dejan caer manifiestos: he recogido algunos: casi todos son monárquicos. Los jóvenes católicos han hecho estos días una propaganda buena, pero quizás es tarde. Sin embargo, la impresión de los buenos es optimista. La proclamación de candidatos por el artículo 29 ha dado 14.000 concejales monárquicos por 1800 republicanos. Veremos a ver mañana.

Domingo 12 de abril: Elecciones de Concejales en España. ${ }^{14}$ Recojo las impresiones del día; escribo a las ocho de la noche. ${ }^{15}$ He ido esta mañana a Madrid para la plática a las empleadas de Hacienda que tengo en las Reparadoras. He atravesado las calles en medio de una paz de día ordinario. He visto poca animación en los centros electorales sin saber a qué atribuirlo y me he vuelto a las doce a Chamartín. ${ }^{16}$ Las visitas de los niños, el teléfono del Debate y personas amigas nos van trayendo noticias del resultado de las elecciones. En Madrid, Barcelona, Sevilla, Valencia, Zaragoza, Bilbao, es decir en las capitales populosas el triunfo de la coalición republicana-socialista ha sido aplastante; en otras ciudades, han triunfado los Monárquicos. En Madrid han sacado todas las mayorías, pero con unas cifras imponentes. La organización dada por la casa del Pueblo era admirable: los chanchullos perfectamente combinados como votar dos o tres veces, votar por los muertos, etc. La propaganda en los mismos centros electorales ofreciendo papeletas de la conjunción republicana ha sido activísima. Yo he visto a varios grupos de muchachas muy ataviadas y procaces, ofreciendo papeletas a los transeúntes; autos adornados de rojo y con carteles francamente comunistas, cargada de jovenzuelos de ambos sexos ofreciendo papeletas. Nuestros jóvenes monárquicos han luchado también en distribuir papeletas, pero la competencia no era posible. Se han visto casos lamentables, aunque pocos. Un párroco, seguido de sus coadjutores que ha ido a votar por la candidatura republicana. Bastante elemento, por no decir mucho, de los buenos y de orden han dado sus votos a los republicanos para demostrar así su odio a la Dictadura y a Primo de Rivera, ${ }^{17}$ y aun para vengarse de alguna ofensa personal que en sus destinos han creído que les ha inferido el Rey.

La propaganda de odio al Rey viene de hace un año haciéndose de una manera brutal en público, en la prensa, en mítines, a ciencia y paciencia del Gobierno Berenguer. ${ }^{18}$

\footnotetext{
${ }^{13}$ Verdoy, A. 1995: 53-55

${ }^{14}$ Tusell Gómez, J. 1970. La segunda república en Madrid: elecciones y partidos políticos Madrid. Villalaín García, P. 1987. Las elecciones municipales de 1931 en Madrid Madrid

${ }^{15}$ Muy distintas fueron las impresiones del socialista Jiménez de Asúa, L. 1931. "Un pueblo ejemplar". "La Libertad". Madrid, 13-5-1931.

${ }^{16}$ El Padre Risco formaba parte de la Comunidad del Colegio del Recuerdo, ubicada en el 'pueblo de Chamartín de la Rosa. El Colegio también era conocido como el Colegio de Chamartín. Sus historia puede seguirse consultando: Colegio de Nuestra Señora del Recuerdo: memoria de sus bodas de oro (1880-1930). 1930: Madrid. Revuelta González. M. 1984 y 1991. La Compañia de Jesús en la España Contemporánea: 822844 y 1196-1201 Madrid: Universidad Pontificia Comillas.

${ }^{17}$ Verdoy, A 1995: 38-44

${ }^{18}$ Echeverría, T. 1966. Sobre la caída de Alfonso XIII. Errores y ligerezas del propio rey que influyeron en su destronamiento: Sevilla
} 
Las noticias de Barcelona acusan un triunfo aplastante del partido separatista capitaneado por un tal Maciá, que según referencias es más que un exaltado, un loco de manicomio. ${ }^{19}$ Las familias de nuestros colegiales, cuenta de la servidumbre de sus casas casos curiosos. Véase uno. La señora pregunta al portero de su casa:

¿Por quién va a votar usted?

Por los republicanos porque me han dado cien pesetas.

Yo le doy otras cien y vota por los monárquicos.

Eso no. Yo quiero que venga la República.

¿Y para qué?

Porque me han dicho que con la república vendrá el caos y que el caos es una cosa estupenda. ${ }^{20}$

Se ha engañado al pueblo de un modo lastimoso; se han repartido entre ellos las casas de Madrid, los autos, las fincas con tal que voten por la República, y esto es lo que llama el Gobierno hacer unas votaciones rabiosamente legales. Entre tanto, se celebra por la tarde Consejo de Ministros y estos demuestran vivir en el mejor de los mundos. Las declaraciones del Conde de Romanones en que atribuye al Gobierno un triunfo por el orden, legalidad y libertad que han reinado en estas elecciones (léanse los diarios del martes) son crueles: el cinismo es revulsivo.

Vienen datos más concretos a última hora. En Barcelona, el partido separatista de Maciá, ha obtenido 26 concejales de los 33 del total; en Sevilla 30 republicanos por 11 de orden; en Oviedo 9 contra 3; en Valencia todas las mayorías que suponen tres contra uno y así todas las grandes ciudades.

Sin embargo, en resumidas cuentas, el triunfo total de concejales en España, sumando los proclamados por el artículo 29, es de la derecha monárquica; pues el resultado total da 22.000 monárquicos y 5.875 antimonárquicos. El triunfo, pues, del elemento derecha es espléndido.

Comienzan a venir más impresiones. El Rey y el Gobierno conceden el triunfo numérico al elemento republicano; pero al fin y al cabo estas son unas elecciones de carácter administrativo y nada suponen para un cambio de régimen; hay que ir a las elecciones de diputados provinciales y luego a unas Cortes Constituyentes que discutan la forma de gobierno que España desea. Esto es la última impresión que queda en el ambiente de Madrid.

Día 13. Lunes: No salgo de Chamartín en todo el día. Comienzan a llegar noticias del aspecto político. Resumen a las nueve de la noche de lo acaecido este día en que nos levantamos monárquicos y nos acostamos republicanos. ${ }^{21}$

Nos vamos dando cuenta de lo que supone el acto de ayer para el porvenir de nuestra pobre Patria. La conjunción republicana-socialista, presidida por don Niceto Alcalá-Zamora, hace ver en un manifiesto que lo que se ha verificado el domingo no son elecciones municipales, sino un plebiscito

${ }^{19}$ Macía i Llusiá, F. (1859-1933). Después de una larga vida parlamentaria y política, fundó en 1919 La Federación Democrática Nacionalista y en 1922 el partido Estat Catalá. Manifiestamente separatista. En 1931, tras su exilio en París, fundó Ezquerra Republicana de Catalunya. El juicio que de Maciá nos ofrece Plá, creemos, está bastante próximo al del padre Risco, Pla, J 1986: 117-120. Arrarás, J. 1964.Historia de la Segunda República española: tomo I: 71-81 Madrid: Editora Nacional. . Soldevilla Zubiburo, F. 1977. Història de la proclamació de la republica a Catalunya: Barcelona

${ }^{20}$ En tono parecido se expresaba en $A B C$, Salaverría, J. M., Madrid, 14 de abril de 1931. Maurín, J. 1932. La revolución española. De la monarquía absoluta a la revolución socialista: Madrid.

${ }^{21}$ Alba, S. 1931. "Por España, con la República”. El Imparcial, Madrid, 19-5-1931. 
nacional donde se pedía el cambio de régimen y como ha triunfado la opinión republicana exige el poder y la abdicación del Rey. Nadie, entre nosotros, cree que Alfonso XIII se decida a dar este paso; sabe muy bien que ese triunfo de ayer es el de una verdadera minoría, que por ser popular y estar pagada con dinero soviético de Rusia, que estos días corrió pródigamente como poco antes para los sucesos de Jaca, ha procurado al elemento republicano un triunfo ficticio, ganado con oro ruso pero no con voluntad nacional. ${ }^{22}$ Creemos que ni el ejército (en especial la Guardia Civil y la Artillería) ni la nobleza, ni el Comercio, ni la Banca, ni los propietarios han de consentir ese paso. Así transcurre la mañana. Vienen noticias de las llamadas que hace el Rey a diversos personajes políticos. El Gobierno parece que no intenta dimitir sino declarar el estado de guerra y seguir hasta la apertura de las Cortes. No nos fiamos gran cosa de este Gobierno. El almirante Aznar no es político, es muy débil de carácter; dentro del gabinete hay elementos de poquísima garantía.

Por la tarde, la zozobra aumenta: el bloque republicano va al triunfo, seguro de la debilidad de los monárquicos y no cede y atenaza a los estados del régimen monárquico. El doctor Marañón, médico republicano, ha conferenciado con Romanones; con ellos han intervenido varios personajes republicanos, que intiman al Conde el que antes de caer el sol se les haya entregado el poder Marañón. ${ }^{23}$ Es esta la voluntad inquebrantable del Sr. Alcalá-Zamora, que espera la resolución desde el despacho del comité republicano.

En palacio se desarrolla gran actividad que nos comunican nuestros amigos. El Rey ha llamado por la mañana a los ministros hacia las 10; luego ha ido llamando por la tarde a don José Sánchez Guerra, ${ }^{24}$ que se ha mostrado defensor de la Monarquía, al Sr. Villanueva, ${ }^{25}$ luego al Sr. Melquíades Álvarez, que se ha declarado republicano desde ayer, y ha conminado al Rey con la necesidad de abdicar enseguida Alvarez. ${ }^{26}$ Se nos ha dicho que el Rey a media tarde ha llamado a los Generales que hay en Madrid para consultarles. Que varios de ellos, sin decirnos sus nombres, se han mostrado dispuestos a defender la monarquía; otros no tienen confianza en la tropa ni en los oficiales jóvenes, de capitán para bajo. Se nos anuncia que el Rey ha propuesto formar una dictadura presidida por don Juan Lacierva, pero que un general (decían que Sanjurjo) se negó a favorecer ésta con la Guardia Civil. ${ }^{27} \mathrm{La}$ verdad de todos estos comentarios no la he podido obtener, ni por ahora creo que se pueda saber lo que pasó históricamente en palacio durante las consultas. ${ }^{28}$ Solo es cierto que al ir cayendo la tarde, el comité republicano, que tiene seguro su triunfo, urge para que se le entregue el poder y que van apareciendo por Madrid manifestaciones francamente revolucionarias. Llegan noticias de que en

\footnotetext{
${ }^{22}$ Comín Colomer, E. 1956. Jaca: Madrid. Azpiroz, J. M. y Broto, F. 1984. La sublevación de Jaca: Zaragoza.

${ }^{23}$ Sobre Marañón: Laín Entralgo, P. 1969. Gregorio Marañón. Vida, obra y persona: Madrid. López Vega, A. 2011. Gregorio Marañón. Radiografía de un liberal: Madrid.

${ }^{24}$ Armiñán, L. 1984. Sánchez Guerra: Madrid. Martorell Linares, M. 2011. José Sánchez Guerra (18591935). Un hombre de honor: Madrid

${ }^{25}$ Villanueva Gómez, M. (1852-1931). Abogado, catedrático de la Universidad de la Habana, miembro del Partido Liberal y ministro en numerosos gobiernos. Junto con Sánchez Guerra formó el grupo de oposición constitucionalista al gobierno de Primo de Rivera.

${ }^{26}$ García Venero, M. 1954 Melquíades Álvarez. Historia de un Liberal: Madrid

27 Sanjurjo Secanell, J. (1872-1936). Militar de carrera y laureado en numerosas ocasiones; fue nombrado Marqués del Monte Malmusi, más tarde marqués del Rif. Alto Comisario de España en Marruecos. Director General de la Guardia Civil, Cuerpo al que puso al servicio de la República. En agosto de 1932 se alzó en armas contra el Gobierno. Condenado a muerte fue indultado gracias a los favores de Azaña. Recuperada su libertad se exilió en Estéril. Falleció el 20 de julio de 1936 cuando se trasladaba a Burgos para encabezar junto con Franco la sublevación contra la República.

${ }^{28}$ Pla, J. 1983: 14-18 describe una situación muy parecida a la presentada por Risco.
} 
Barcelona se ha proclamado la República catalana hacia las cuatro de la tarde y en Zaragoza y en Eibar y en otros sitios.

Nuestro ánimo está aplanado; nos parece que soñamos una pesadilla. A las cinco de la tarde vino a verme mi hermana. Madrid, según ella, no presenta un aspecto de desorden; muchos grupos, muchos camiones con gente y emblemas rojos y la Guardia Civil tomando los pasos de la Castellana.

En la sala de visitas entra una familia conocida: vienen todos llorando; les pregunto que qué pasa y me dicen:

"En el balcón del Ayuntamiento se ha izado la bandera roja y se ha proclamado la República. Dicen que el Rey se va esta tarde a Lisboa, porque acaba de abdicar".

Se habla de una abdicación en regla por documento firmado en que renuncia a la corona de España por si y por sus descendientes". La realidad no ha sido esa. Consultado el actual gobierno, los generales y los políticos y viendo que no puede sostenerse más que amparado por una guerra civil ha entregado los poderes a la República por vía de hecho, sin documento ninguno, diciendo: "Quiero demasiado a España para provocar un acto de fuerza".

El Rey ha salido a las ocho y media de la noche en el expreso para Cartagena. La familia real queda en Palacio y marchará al Escorial para continuar camino de Francia. Dicen que el Rey ha mostrado una entereza y una serenidad grandes. ${ }^{29}$ Le acompañan en el viaje el infante don Alfonso de Orleáns, el almirante Sr. Rivera y el Duque de Miranda, don Luis de Silva. ${ }^{30}$

Día 14. Martes: ${ }^{31}$ Impresiones de la marcha de nuestros Monarcas. El Rey no ha ido en un tren sino en auto a Cartagena, donde llegó a las cuatro de la mañana, e inmediatamente se dirigió, hoy martes, al crucero Príncipe Alfonso, oyendo vivas y mueras. El crucero zarpó a las cinco y cuarto para Marsella. La Reina y los infantes quedaron en palacio para salir mañana en auto hasta el Escorial. ${ }^{32}$

Entre tanto a las dos de la mañana se posesionaba el Presidente de su cargo en la Presidencia con varios Ministros que estaban en Madrid. La república ha quedado en manos de los siguientes señores:

Presidente; D. Niceto Alcalá-Zamora.

Estado: D. Alejando Lerroux

Gracia y Justicia: don Fernando de los Ríos.

Gobernación, don Miguel Maura.

Hacienda, don Indalecio Prieto.

Fomento: don Álvaro de Albornoz

Instrucción, don Marcelino Domingo

Ejército, don Manuel Azaña.

Marina, don Santiago Casares Quiroga

Economía, don Luis Nicolau d'Olwer

Trabajo, don Francisco Largo Caballero

\footnotetext{
${ }^{29}$ Marañón, G. 1931. "La monarquía ha muerto de enquistamiento. Comentario primero. El Sol, Madrid 21-5-1931.

${ }^{30}$ Sobre el rey Alfonso XIII: Vallotton, H. 1943. Alphonse XIII: Lausanne. Almagro de San Martín, M. 1947. Ocaso y fin de un reinado. Alfonso XIII. Los reyes en el destierro: Madrid. Carlavilla, M. 1956. El Rey. Radiografía del reinado de Alfonso XIII, dos volúmenes: Madrid. Seco Serrabo, C. 1979. Alfonso XIII y la crisis de la restauración: Rialp Madrid.

${ }^{31}$ Galindo Herrero, S. 1953. El 14 de abril: Madrid.

${ }^{32}$ Gómez Santos, M. 1964. La reina Victoria Eugenia de cerca: Madrid. Arrarás, J. 1964: 59-66.
} 
Comunicaciones, don Diego Martínez Barrios

¡Pobre España! La gente madrileña, que para poner apodos políticos no tiene rival, ha calificado al Gobierno diciendo "que es un gobierno ferroviario: porque todos los ministros son expresos". En efecto, o en tiempos de la Dictadura o en el gobierno Berenguer todos han estado presos en la cárcel. ${ }^{33}$ Los nuevos ministros tienen precedentes muy negros respecto de su filiación católica (masones claros, ${ }^{34}$ a excepción del Presidente y Maura y tal vez Prieto de quienes se duda). ${ }^{35}$ Veremos a ver cómo enfocan el problema religioso. ${ }^{36}$

La noche que han pasado la Reina y los infantes en Palacio ha sido de zozobra y de prueba. Me han dicho que sabían las intenciones de las turbas de asaltar el palacio real y aun de profanar las personas reales como en Rusia, y que varios de los que con ellas estaban tenían la intención de no permitirlo aun a costa de la vida propia y aún de ellas.

En efecto, la tarde y la noche de este día 14 han sido de un salvajismo indecible, sin precedentes; no hay palabras bastantes para expresarlo. Léase el Debate del miércoles 15 o la Nación o el ABC. Según las referencias que tengo; ya desde las cuatro de la tarde, se organizó en la Plaza de la Villa la primera manifestación contra las personas reales. Bajaron tumultuosamente a la Plaza de Oriente dando mueras y chillidos y las dispersó la Guardia Civil. A medida que avanzaba la tarde, los grupos se iban formando por todas partes y engrosando: por la noche y hasta las cuatro de la mañana Madrid ha sido un infierno. Las cosas que me han contando llenan de ira al ánimo más sereno. Los grupos estacionados en la Plaza de Oriente, con ánimo hostil a la familia real, consiguió por fin impedir la circulación de autos y tranvías. Los gritos más soeces llegaban sin duda a los oídos de la Reina; el príncipe está enfermo en cama. Dicen que llegaron a asaltar los balcones, cuando una orden del Ministro de Gobernación hizo retirar a la Guardia civil, que al retirarse fue ovacionada por burla. Quedó aquello bajo la tutela de la Guardia cívica o sea de paisanos con un brazalete rojo al brazo y con más republicanos que las turbas se la dan de mantenedores del orden. Por fin, llegó un piquete de bomberos: uno de ellos subió a los balcones o puso en las puertas un letrero que decía: "Ciudadanos, respetad este edificio, que es vuestro". Otros colgaron los balcones de palacio con banderas republicanas. Cuando la turba vio que la entrada en palacio estaba defendida, desistió de entrar y se dio a cometer salvajadas. En la plaza de Isabel segunda, derribaron la estatua de esta reina, que es una obra de arte en bronce, y la llevaron arrastrando hasta la Puerta del Sol. En la plaza Mayor derribaron la estatua ecuestre de Felipe IV, también de bronce y arrancaron la cabeza al caballo, que aún no ha aparecido. Entre tanto, otra masa de las turbas por la calle de Alcalá saqueaba y robaba la editorial Voluntad; allanaba el domicilio de la Acción Ciudadana de los albiliñistas, arrancando los rótulos de las calles que tenían nombres monárquicos, como el de la calle de la Reina, de las Infantas, etc.

Al cerrar del todo la noche, dicen que el escándalo no tenía nombre para ser calificado: era el infierno. La Puerta del Sol, el Carmen, Preciados, Alcalá eran una masa de condenados. Camiones con obreros y mujerzuelas berreando; masa que se movía sin saber ya ni a qué cosa decir que muriese o que

${ }^{33}$ A propósito de chistes, recuerdo que cuando Primo de Rivera sustituyó la dictadura de militares por algunos de profesión civil, se formó el Gobierno por cinco generales y tres paisanos. Los madrileños le calificaron diciendo que formaban el Gobierno "cinco espadas y tres vainas". Estos resultaron después hombres de mucho mérito, escribe en nota Risco. .

${ }^{34}$ Gómez Molleda, Mª D. 1986. La masonería en la crisis española del siglo XX: Madrid.

${ }^{35}$ Sobre los Ministros y sobre su capacidad e identidad puede leerse el artículo de Fernández Flórez, W. 1931 "Los futuros ministros". $A B C$ : Madrid, 1-12-1931.

${ }^{36}$ Marañón, G. 1931. "El problema religioso. La sugestión del mito”, El Sol: Madrid 13-11-1931. De la Serna, V. "1932. "Clérigos y abogados": La Voz, Madrid, 17-6-1932. 
viviese. Los hombres cogían a las prostitutas y modistillas medio desnudas y aun dicen que algunas desnudas con una banda roja y las echaban a los camiones como fardos donde eran recibidas con gritos: se realizaron los actos carnales en toda su crudeza por la Puerta del Sol; ${ }^{37}$ por las calles de Alcalá y del Carmen se formó una procesión de ambos sexos con rosarios y velas, cantando las groserías más inmundas, y dentro del palacio de Gobernación que está en la Puerta del Sol los prohombres de la República gozándose con el expansionismo del pueblo. A eso de las dos de la mañana se abrieron los balcones de dicho ministerio y se asomó un señor para decir al pueblo que el Gobierno había dado una general amnistía a todos los presos de las cárceles de España, exceptuando algunos delitos monárquicos (los monárquicos) y que a las ocho de la mañana llegarían a Madrid el general Queipo de Llano ${ }^{38}$ y el comandante Franco, dos desterrados del gobierno Berenguer. Franco, en efecto, se ha portado muy villanamente con la Monarquía. Sabemos que en el último vuelo a América que fue un fracaso, había sustituido clandestinamente los motores del hidro que eran españoles por otros de una Casa italiana para hacerle la propaganda y sabemos que el Gobierno de Primo de Rivera se gastó varios millones (dicen que once) en salvarle la vida cuando se cayó al mar, y se lo está pagando...

Estas son las impresiones generales de esta triste noche. De Barcelona y demás partes de España llegan horrores. Maciá está dispuesto a independizar a Cataluña.

\section{Día 15. Miércoles.}

El Rey ha dejado un manifiesto a la nación, que copio literalmente del Debate de hoy: "Las elecciones celebradas el domingo, me revelan claramente que no tengo hoy el amor de mi pueblo. Mi conciencia dice que ese desvío no será definitivo, porque procuré siempre servir a España, puesto el único afán en el interés público hasta en las más críticas coyunturas. Un rey puede equivocarse, y sin duda erré yo alguna vez, pero sé bien que nuestra Patria se mostró en todo momento generosa ante las culpas sin malicia. Soy el Rey de todos los españoles y también un español. Hallaría medios sobrados para mantener mis regias prerrogativas en eficaz forcejeo con quienes las combaten; pero resueltamente quiero apartarme de cuanto sea lanzar un compatriota contra otro en fratricida guerra civil. No renuncio a ninguno de mis derechos, porque más que míos, son depósito acumulado por la Historia, de cuya custodia ha de pedirme un día cuenta rigurosa. Espero a conocer la auténtica y adecuada expresión de la conciencia colectiva y mientras habla la Nación, suspendo deliberadamente el ejercicio del Poder real y me aparto de España, reconociéndola así como única señora de sus destinos. También ahora creo cumplir el deber que me dicta mi amor a la Patria. Pido a Dios que tan hondo como yo, lo sientan y lo cumplan los demás españoles". ${ }^{40}$

¡Pobre Rey! El amor hondo y respetuoso que le tenía el pueblo se lo han ido quitando los periódicos malvados, que a ciencia y paciencia de los Gobiernos anteriores, la Dictadura por debilidad con ellos, Berenguer por.... Diremos más debilidad todavía, esos periódicos, océanos de Asociaciones anárquicas han ido filtrando día a día en la clase obrera el funesto Ateneo de Madrid, institución

${ }^{37}$ Pla, J. 1983: 21. Plá con menos crudeza que el jesuita describe una escena parecida: "Como en todos los espectáculos de masas, las posaderas del sexo femenino pueden ser manoseadas más o menos por personas que no tienen nada de republicanas. Pasan, sobre la multitud, ráfagas de entusiasmo cívico que determinan movimientos de ternura humana. ¡Un día es un día!. Después Dios dirá...”.

38 Olmedo Delgado, A. 1958. General Queipo de Llano (aventura y audacia): Barcelona. Gibson, I. 1986. Queipo de Llano. Sevilla, verano de 1936: Barcelona.

${ }^{39}$ Garriga Alemany, R. 1978. Ramón Franco, el hermano maldito: Barcelona.

40 Este y otro mensaje fueron redactados en el transcurso del viaje real de Cartagena a Marsella. Algunos de sus colaboradores como el almirante Rivera pensaron, al decir de Arrarás, que no se publicarían. Ciertamente se equivocó. Arrarás, J. 1964: 68 
claramente antimonárquica, mimada, temida y subvencionada por los Gobiernos de Madrid; ${ }^{41}$ la Institución Libre de Enseñanza pagada pingüemente por el Estado para que le siembren en las Universidades de Medicina y de Derecho el desprecio a la autoridad y a Dios, todos estos elementos han matado en el pueblo, en los estudiantes, en la clase culta o intelectual como ellos se llaman ese amor al Rey que él cree que volverá. Dios lo quiera. Tenemos el ejemplo de la F. U. E (federación universitaria de estudiantes) vida y alma de los motines callejeros y universitarios minada, ${ }^{42}$ temida, vilmente anulada por el último funestísimo ministro de Instrucción pública don Elías Tormo, cuya incapacidad profesional dejará rastro en la Historia. ${ }^{43} \mathrm{Y}$ este ministro, católico, persigue y niega toda intervención de la Federación de Estudiantes Católicos. Estas premisas no han podido dar otra conclusión que la que han dado, que la que darán.

El Rey llegó hoy a Marsella, donde se le recibió con muestras de extraordinaria simpatía, en tanto que el Gobierno francés es el primero en reconocer la República española. Salió de Marsella en el rápido de París y llegó a la capital de Francia.

La familia real, la Reina e infantes salieron esta mañana en automóvil para el Escorial donde en un Coche Pulman especial se han dirigido a San Sebastián para unirse al Rey en París. La salida ha sido muy triste; muchos lágrimas y en los andenes algunos gritos de odio. El corazón del pueblo español está envenenado por las causas dichas, con odio a sus reyes y a Dios.

Hoy ha sido declarado fiesta nacional, ${ }^{44}$ como si los escándalos de ayer no bastasen todavía. Desde la torre del Observatorio de Chamartín he visto con mis prismáticos algunas escenas pintorescas. Niños y niñas con las narices llenas de mocos y los gorros colorados en la cabeza corriendo y chillando por el campo. Es fiesta nacional y se ha decretado el paro general del trabajo y la clausura de todos los establecimientos, aún del comestible a excepción de las tabernas. Tenemos que proveernos de carne y pan la víspera en el Colegio; así lo han hecho todos en Madrid.

La gente se echó a la calle desde las nueve de la mañana. El paro se extendía a oficinas públicas y privadas, taxis y todo medio de locomoción, excepto el metro y tranvías. El golpe fuerte comenzó en la Plaza de Oriente, los estudiantes, ferroviarios y obreros y las mujerzuelas renovaron la escena de la tarde anterior, en donde varios de los hombres arracimados en los tranvías habían caído o se habían estrellado contra los postes de la corriente, muriendo algunos de ellos.

A las once la ola humana, aulladora, borracha, asalta los tranvías, se sube en los techos del trole, abarrotan el metro, por supuesto sin pagar. Madrid es un hormiguero de carne revuelta, sobre todo Puerta del Sol, Alcalá, Castellana, Rosales. Así toda la tarde y toda la noche. Dicen que un grupo quiso poner un gorro frigio o una bandera roja a la estatua de Santa Teresa que hay en la fachada del convento de carmelitas de la Plaza de España. Bastó la actitud resuelta de una señora y de un joven que se opusieron para hacerles desistir. Por la noche, vuelta a las procesiones irreverentes y grotescas, entierro de un muñeco representando al Rey o a Gutiérrez, que es el apodo que le han puesto.

${ }^{41}$ Pla, J. 1983: 57-61, su opinión, un poco más matizada, no difiere mucho de la de Risco. Ruiz Salvador, A. 1976. Ateneo, dictadura, república: Valencia: Fernando Torres.

${ }^{42}$ González Calleja, E y Souto Kustrin S. 2007. "De la Dictadura a la República: Orígenes y auge de los movimientos juveniles en España. Hispania: 225: 73-102.

43 Tormo y Monzó, E. (1869-1957). Profesor universitario, llegó a ser Rector de la Universidad de Madrid. Ministro de Instrucción Pública en el Gobierno Berenguer. Académico de la Historia y especialista en arte y arqueología.

${ }^{44}$ Plá J. 1931. "Un día de fiesta nacional”. La Veu de Catalunya: Barcelona 20-4-1931, tomado del libro de Plá, J. 2006. La Segunda República Española. Una crónica (1931-1936): 61-63 Barcelona: Destino 
Hoy se ha dado un decreto por el cual el Gobierno se incauta del Palacio real; sus habitaciones se han cerrado y sellado hasta que se haga el inventario de lo que en él han dejado los reyes.

Se están contando anécdotas muy curiosas sobre la candidez con que ha sido engañado el pobre pueblo para que traiga la república. Se les ha repartido imaginariamente toda España y ahí van datos: me cuenta una señora que tenía tres criadas, una vieja y dos jóvenes. Ayer estuvieron de disputa las dos jóvenes todo el día, La señora llamó por fin a la vieja y le preguntó que porque reñían. Ella le dijo: Mire, señora, voy a decirle la verdad. Es que en el reparto general no ha tocado a las tres este piso. Como yo no soy avariciosa me he contentado con tales y tales muebles. Esas dos se han repartido lo demás, pero esa bandeja de plata que tenía usted en el aparador se le ha antojado a las dos y ninguna quiere ceder.

Otra anécdota también histórica. Anteayer fueron dos señoras de las Conferencias a visitar a sus pobres en uno de los barrios misérrimos de Madrid ${ }^{45}$. Una de las pobres socorridas, mujer ya de edad con varios hijos famélicos, recibe a sus protectoras con amable sonrisa: recibe sus bonos y en medio de la conversación les dice a las señoras:

Yo quedo agradecidísima a la caridad con que me han socorrido ustedes, y yo les aseguro que en adelante quedan bajo mi protección y verán como no les faltará a ustedes nada. Extrañados de aquel lenguaje las señoras piden explicación y resulta que desde la semana siguiente todo lo de los ricos, todo iba a ir a los pobres, y se volvería al revés la tortilla social y por lo tanto.....

Otra señora me cuenta que tenía a su servicio a una muchacha de unos 25 años, fiel y trabajadora. Por mutuo acuerdo el ama guardaba los ahorros de la criada y los aumentaba con frecuentes propinas a fin de reunir un par de miles de pesetas y que le sirviesen de dote al casarse con su novio, que estaba empleado en ferrocarriles, que era un chulo guapetón y holgazán, que no ahorraba nada..... Así llevaban hacía tres años el noviazgo.

"Hace unos días dice la señora, se me presentó la muchacha pidiéndome sus ahorros, porque quería casarse enseguida. Le pregunté el por qué y dijo: Señora en el reparto le han tocado a mi novio dos pisos de la casa número 2 de la Calle Mayor. Pensamos casarnos, vivir en uno y alquilar otro".

No hubo medio de convencerla y la señora tuvo que darle los ahorros, unas 1500 pesetas. Ayer, añadía la señora, se me presentó la muchacha llorando a moco tendido. El granuja del novio se le había ido con los ahorros y la había dejado al aire libre. ¡Los hay frescos! De estas me las cuentan a montones. El Gobierno provisional de la República entra en una fase de hambre canina de decretar. Hoy han salido varios, que dan una idea de lo que estos señores piensan hacer. Van varios. $1^{\circ}$. La incautación sin demora del palacio real. $2^{\circ}$. Abriendo tres procesos distintos para exigir responsabilidades sobre el desastre de Anual en Marruecos; sobre los actos de la Dictadura de Primo de Rivera; y revisión del juicio sumarísimo que precedió al fusilamiento de los capitanes Galán ${ }^{46}$ y García Hernández. El nombre de Galán y el de todos los que intervinieron en el alzamiento de Jaca son nombres de héroes y de Mártires; ya tienen calles y plazas a su nombre en varios sitios de España. $3^{\circ}$. Anunciando normas y represalias contra la salida de los capitanes españoles, que se trasladan a Bancos extranjeros: el decreto sólo anuncia que se darán esas normas; $4^{\circ}$. La concesión de indulto general para los presos, que hoy se ha ejecutado. Toda clase de criminales que tenían condena de menos de cuatro años se han visto al aire libre, y aplaudidos y saludados como si fuesen hombres de bien. Veremos a

\footnotetext{
${ }^{45}$ Con toda seguridad se está refiriendo a las Conferencias de San Vicente de Paul, fundadas en París en 1833 entre otros por el hoy beato Federico Ozanan (1813-1853)

${ }^{46}$ Bertrand Fauquenot, L. F. 1985. "Galán, verdad y mito". Historia 16 109: 11-32
} 
ver cómo se buscan la vida honradamente. Esto en Madrid, lo mismo se ha hecho en toda España y habrá que ver. $5^{\circ}$ decreto derogando el código penal con tanta trabajo y consultas elaborado por el ministro de la dictadura Galo Ponte en 1928. $6^{\circ}$ disolviendo los somatenes, especie de milicia formada por el paisanaje para defensa de las ciudades que formó la Dictadura. $7^{\circ}$ decreto concediendo a la madre del capitán Galán y a la viuda del capitán Hernández "mártires de la libertad" (ya sólo la frasecita) y de la república española fusilados en Huesca el 14 de diciembre de 1930 "la paga en activo de dichos mártires, los cuáles irán ascendiendo en el escalafón como si estuvieran vivos.

No hay que decir que todos los cargos públicos, chicos y grandes, y todas las Embajadas en el extranjero han sido o dimitidos o admitida la dimisión y comienzan a subir los vencedores. Algunos tienen verdadero mérito; en general dan la impresión de que la República o no cuenta con los hombres de talla o pospone el mérito al compadrazgo.

En Sevilla las fiestecillas de la República han concluido con la declaración del estado de guerra proclamado por el capitán general Cabanellas, que es un hombre de cuerpo entero. ${ }^{47}$ Los horrores que se cuentan de Sevilla durante las dos fiestas pasadas no son para contarlos, ${ }^{48}$ y lo mismo en el resto de España. Estamos empeñados en que las naciones formen una jaula de hierro de las proporciones de la Península y nos encierren en ella.

Cataluña sigue forcejeando por declarar su autonomía; el gobierno de Madrid le dice con corteses palabras que "perdone, por Dios, hermanita".

Día 16. Jueves. Calma en el pueblo. He ido a Madrid y la vida se desliza como de ordinario. En cambio, el Gobierno provisional de la República se siente cada vez más molestado por la urticaria decretista $^{49}$. Ahí van decretos. Las elecciones de concejales que dieron el triunfo a la república, dio como vimos una buena mayoría de ayuntamientos monárquicos; estos le estorban al Gobierno y en virtud de esta molestia hoy sale un decreto para que en los ayuntamientos en donde "se hayan denunciado desórdenes durante la votación" (es decir en los ayuntamientos de mayoría monárquica) se proceda a una nueva votación, nombrándose una Comisión gestora que prepare nuevas elecciones. Otro decreto suprimiendo en el Senado, las senadurías vitalicias y de derecho propio (las que gozaban los grandes contribuyentes, parte de la Nobleza y varios prelados).

Otros muchos con nombramientos de altos cargos y admitiendo dimisiones. Es muy curioso el nombramiento de la señorita Victoria Kent como directora general de Prisiones (es vieja y fea y..... de historia). ${ }^{50}$ Otro disolviendo el cuerpo de alabarderos: dejando cesantes a todo el personal de la Casa real. Se ha hecho pública la lista de los nuevos gobernadores de provincia. Dios se la depare buena a algunas provincias de España porque el Gobierno provisional les envía de regalo algunos gobernadores que ni fabricados en Madrid. Ha llegado a Madrid el general Queipo de Llano y el

${ }^{47}$ Cabanellas Ferrer, M. (1872-1938). Militar de carrera con larga trayectoria primero en Cuba y más tarde en Marruecos. Será uno de los generales que apoye el llamado Alzamiento Nacional.

${ }^{48}$ Arrarás, J. 1964: 70

49 Sobre los decretos puede verse el Repertorio Aranzadi cronológico de legislación 1931: Pamplona. Guimera López, C. 1987. "La segunda república y la corona (análisis jurídic de la legislación antimonárquica". Hidalguía 201: 373-385

${ }^{50}$ Kent Siano, V. (1898-1987). Abogada malagueña que defiende en el Tribunal Supremo de Guerra y Marina a Álvaro de Albornoz, miembro del Comité Revolucionario y más adelante miembro del Gobierno provisional de la República. Fue la primera mujer en el mundo que intervino ante un Consejo de Guerra consiguiendo la absolución de su defendido. Diputada por el Partido Radical Socialista y Directora General de Prisiones de 1931 a 1934. Gutiérrez Vega, Z. 2001. Victoria Kent: una vida al servicio del humanismo liberal: Málaga. 
comandante Ramón Franco, ${ }^{51}$ los amigos de Galán; el uno para ser capitán general de Madrid, el otro como jefe de toda la aeronáutica española, etc. Franco, dicen que dijo Lerroux o alguno de los ministros, que es lástima que no se ahogase en el percance del vuelo a América, pues si se hubiera ahogado España tendría "un héroe más y un sinverguenza menos". La recepción ha sido apocalíptica, con discursos, salidas al balcón. Se van nombrando embajadores para el extranjero. A Londres va Ramón Pérez de Ayala, el que comenzó a hacerse célebre escribiendo la novela A.M.D.G. llena de calumnias deshonestas contra los jesuitas, algunos de ellos profesores suyos. ${ }^{52}$

Día 17. Viernes. El pueblo soberano se ha declarado enemigo implacable del general Berenguer. En las algazaras de los días anteriores se formaron grupos imponentes que recorrieron las calles de Madrid y se estacionaron en la Puerta del Sol aturdiendo a los pacíficos habitantes con los gritos de: Una, dos, tres, muera Berenguer. Complicado se halla en las responsabilidades que quieren pedirse de Anual y del fusilamiento del capitán Galán. Se dijo que había huido de España con el general Mola que decretó el fusilamiento. Hoy se han presentado los dos para que se les encarcele si hay motivo. Dicen otros que es una pamema tremenda con el Gobierno para acallar al pueblo y libertarlos. No se les ha encarcelado.

La Generalidat (sic) de Cataluña y el Gobierno de Madrid parece que han venido a un arreglo. Sin embargo, ni Cataluña ni las Provincias Vascongadas, creo que cedan. El Gobierno ha acordado que los días festivos no hay misa oficialmente en los cuarteles: asistirán sin formación la oficialidad y tropa que quiera. Se han quitado de los uniformes y demás sitios y prendas los emblemas de la monarquía, la corona, toisón, etc

La simpática infanta doña Isabel, ${ }^{53}$ a quien por estar enferma se le habían ocultado los sucesos y la ida de los Reyes, al saberlo todo ha mostrado su voluntad inquebrantable de emigrar también. ${ }^{54}$ Era por su carácter de ídolo de la gente pobre de Madrid.

El Nuncio habla en nombre del Papa. El sumo Pontífice es indiferente a una u otra forma de Gobierno y de hecho acepta el de España y se persuade de que seguirá protegiendo las creencias religiosas..... 55

He ido a Madrid que sigue la vida ordinaria.

${ }^{51}$ Franco Bahamonde, R. (1896-1938). Militar del arma de Infantería, en 1920 pasó a la Aeronáutica Militar. Alcanzó fama mundial al cruzar el Atlántico desde Palos de Moguer (Huelva) a Buenos Aires. Participó en la sublevación de Cuatro Vientos por lo que fue encarcelado. En 1931 fue elegido diputado a Cortes representando a la Ezquerra Republicana. Zabala, J.M.. 2009. Franco, el republicano: la vida secreta de Ramón Franco, el hermano maldito del Caudillo: Barcelona.

${ }^{52}$ Pérez de Ayala, R. (1880-1962). Educado por los jesuitas y estudiante interno de los Colegios de San Zoilo y Gijón. Buen escritor, formado por el entonces jesuita Julio Cejador Frauca, que poco después abandonó la Compañía de Jesús. Autor junto con Ortega y Gasset y Gregorio Marañon del Manifiesto a la República. Freira Suárez, F. 1997. Ramón Pérez de Ayala: testigo de su tiempo: Gijón.

${ }^{53}$ La Infanta Isabel era hija de Isabel II y de Francisco de Asís, hermana de Alfonso XII y tía de Alfonso XIII. Con el cambio de régimen y a la edad de ochenta años decidió salir de Madrid y de España. Partió el 19 de abril, muriendo en la localidad de Auteuil cuatro días después.

54 Sobre la emigración y los exiliados en la Segunda República Gónzález, N. 1983. Los exiliados monárquicos durante la II República en La $2^{a}$ República. Coloquio Internacional sobre la II República: $35-57$. Barcelona: Universidad de Barcelona.

${ }^{55}$ Puede verse sobre el particular el editorial del día 15 de abril de El Debate, Ante el poder constituido; en él se aceptaba, en consonancia con lo mejor del pensamiento político de León XIII, el cambio de régimen. 
Día 18. Sábado. Los reyes de España siguen en París sumamente agasajados. La infanta Isabel persiste en marcharse a París.

Día 19. Domingo. Esta noche a las ocho ha marchado la Infanta Isabel a París. Hoy llegó a Irún. Sigue la picazón de reformas en los ministerios. Plan de reforma del ejército; plan de reforma del Tribunal Supremo. El ministro de Justicia anuncia que para las Cortes tiene preparado un decreto de separación de la Iglesia y del Estado. Trata también de dar un decreto sobre la libertad de cultos y la secularización de los cementerios. Ya empiezan a asomar la oreja.

Comienzan a volver al colegio de Chamartín los alumnos internos que se fueron atemorizados con el advenimiento de la república. Tenemos en Chamartín 240 alumnos internos, más unos 20 externos. Al día siguiente de la proclamación de la república y otros días siguientes se presentaron en el colegio varios papás de alumnos internos para llevárselos a sus casas. Eran de Andalucía. El padre Rector $^{56}$ los dejó ir, avisándoles que si la actitud de España recobraba la calma los trajeran, pues el fin de curso se avecina. Como la calma parece que renace, están volviendo. Ha traído la tranquilidad al colegio una misión secreta que ha recibido el padre Rector del parte del Presidente. El Sr. Alcalá Zamora ha hecho llegar al Padre Rector por medio de un amigo de la Compañía este mensaje verbal: "Que ha sabido que varios niños del colegio, llevados de infundada alarma, han salido para sus casas. El presidente desearía que volviesen, dando para ello el máximun de garantías; que no tengan temor ninguno y que se reanuden las clases normalmente. Que la impresión de seguridad en un colegio como el de Chamartín cederá en bien de la república, porque esta quiere dar esa sensación de completa normalidad".

Con estas seguridades los niños han vuelto todos y el colegio sigue su vida normal. He estado en Madrid y he comido en la casa profesa (sic). ${ }^{57}$ Todos los padres están dominados de un pesimismo muy negro; ven que se avecinan sucesos desagradables para la Iglesia y en especial para nosotros. Casi todos los padres se han hecho traje de seglar. Me dicen que en la villa de San José, o sea en la residencia de los escritores ${ }^{58}$ también tienen hechos trajes de paisanos, y creo que también en el Colegio de Areneros. ${ }^{59}$

En efecto, entre los católicos el pesimismo se masca. Esta calma en la que vivimos hace tres días no calma los espíritus; la tormenta de la persecución se está formando a no dudarlo. El ministro de Justicia, Fernando de los Ríos, es un sectario refinado y violentísimo; el de Instrucción es un ateo, que debe su carrera a la intriga y a su cinismo antirreligioso; ${ }^{60}$ el de Guerra quizás gane a ambos en todos los sentidos, y los demás no les van a la zaga a los nombrados. Se sabe que tienen compromisos contraídos con los soviets rusos y que el dinero ruso circula por España con verdadero derroche. El

${ }^{56}$ El Padre Rector del Colegio de Nuestra Señora del Recuerdo era a la sazón el padre Enrique Jiménez Tarroni. Nacido en Talavera de la Reina (Toledo) en 1876, morirá en el Colegio del Recuerdo en 1950.

${ }^{57}$ Se está refiriendo a la Residencia que la Compañía de Jesús tenía en la Calle de Flor y que días más tarde sería pasto de las llamas. Las Casas Profesas eran aquellas en las que residían jesuitas, libres de otros trabajos, a la acción pastoral directa. Estas Casas tenían dentro de la legislación canónica de la Compañía un estatuto especial.

${ }^{58}$ Se está refiriendo a la Casa en la que residían los padres escritores y donde tenía su sede, entre otras, la Revista Razón y Fe. Dicha Casa estaba y está en la Calle Pablo Aranda 3.

${ }^{59}$ Dicho Colegio no era otro que el Colegio de Segunda Enseñanza de la Inmaculada y San Pedro Claver, ubicado en la calle Alberto Aguilera 23. Dicho Colegio compartía espacio y lugar con la Escuela de Ingenieros del ICAI. Revuelta González, M. 2008: 817-822. Sanz de Diego, R. Mª 2009. ICAI: 1908-2008: lo que fuimos, lo que somos: Madrid: Universidad Pontificia Comillas.

${ }^{60}$ Zapatero, V. 1999. Fernando de los Ríos.: biografia intelectual: Granada-Valencia: Pre-TextosDiputación Granada. 
alzamiento de Jaca se hizo con dinero de una venta de madera, cortada en Rusia, vendida con un 30\% de rebaja sobre su precio en España y dejando el producto para pagar el alzamiento. Los periódicos sobre todos los extranjeros dan la voz de las reuniones de la Internacional donde se ha votado un crédito especial para el triunfo del comunismo en España. Las capitales de Andalucía, en especial los puertos de mar, nos consta que son nidos de comunismo. Este es el ambiente. Nosotros en Chamartín no hemos pensado en hacernos traje; yo soy de la opinión de que conviene pensar en eso, aunque mi carácter y genio me hacen excesivamente optimista.

Me he encontrado con un Jefe de la marina amigo mío y está muy pesimista; dice que el comunismo está minando las dotaciones de los barcos y de los arsenales. Yo quiero ser optimista y las noticias de pesimismo me acorralan.

Día 20. Lunes. Los periódicos hablan del viaje de la Infanta Isabel. Era todo bondad, todo compasión y todo españolismo. Le gustaba meterse entre la gente pobre de los barrios en las verbenas: vivir en contacto con sus madrileños que la querían a rabiar. Va muy enferma, casi tullida y ha salido de Madrid como un criminal que huye, ${ }^{61}$ sin que su pueblo querido tenga para ella una frase de cariño. Ha instalado su residencia en la Pensión de Damas de la Asunción de Neuilly-Sur-Seine.

La desbandada de gente rica, de la nobleza y de los que tienen algo que perder se hace ya imponente. En vano el Gobierno pretende atajar la emigración del capital español. Es que todos temen los desmanes de la gente del ampa (sic): es que se propalan en los periódicos radicales los proyectos más absurdos y se dicen las burradas más atroces sin que nadie las refute. Hoy se ha dado un decreto sobre la salida de los capitales de España. No se permite sacar en metálico por la frontera más de 5.000 pesetas por persona. $^{62}$

Decreto sobre la incautación de los bienes del patrimonio real. La Casa de Campo y el Campo del Moro, posesiones reales, pasan al Ayuntamiento. Me he enterado de que en Cartagena se ha sublevado la dotación del crucero Blas de Lezo contra su comandante y lo han echado del barco. Lo sentiría pues es muy amigo mío y un católico de comunión diaria, don Guillermo Ferragut y tiene dos hermanos jesuitas.

El ayuntamiento de Gijón, reunido en pleno, decreta pedir al Gobierno la expulsión de la Compañía de Jesús, por ser contraria al verdadero progreso y a la civilización, etc, etc. ${ }^{63}$ Esto fue hace unos días. Hoy leo en el Debate una protesta corporativa del ayuntamiento de Lequeito (Guipúzcoa) contra Gijón. Esta villa o ciudad de Gijón no sé qué tiene contra nosotros. Hace un mes, antes de la República, asaltó nuestra Iglesia y destrozó los altares y los nuestros se salvaron de milagro. Hoy da el primer grito pidiendo nuestra expulsión de milagro. ${ }^{64}$ También se registran chispazos de persecución religiosa en Zaragoza, Cádiz ${ }^{65}$ y otros sitios.

Los periódicos católicos se ponen en guardia contra los decretos anunciados por el ministro de Justicia. El de Instrucción está volviendo patas arriba los cargos de universidades, institutos, etc. Está

${ }^{61}$ El 19 de abril abandonó su palacio de la Calle Quintana; "imposibilitada por los achaques... y tendida en una camilla, fue llevada hasta una ambulancia, que la trasladó hasta El Escorial, y desde allí, por tren a París": Arrarás, J. 1964: 89-90

${ }^{6}$ Ídem

${ }^{63}$ Sobre el particular puede verse la información que remite Tedeschini a Pacelli en Cárcel Ortí, V. 2011: 317. Despacho de Tedeschini a Pacelli, Madrid 6-5-1931.

${ }^{64}$ Verdoy A. 1995: 69 y Radcliff P.B. 2004. De la movilización a la Guerra Civil: historia política y social de Gijón (1900-1936): Barcelona: Debate.

${ }^{65}$ Caro Cancela, D. 1985. "Una aproximación al anticlericalismo contemporáneo: la quema de los conventos de mayo de 1931”. Gades 13: 241-252 
poniendo todo lo más ateo que encuentra. Por más que en los otros ministerios se está haciendo lo mismo.

Día 21. Martes. Nuestros reyes han estado en Inglaterra donde se les han hecho calurosas demostraciones de afecto. El infante don Juan ingresará como guardia marina en la armada inglesa. ${ }^{66}$ Los reyes se establecerán en un hotel como personas populares en los alrededores de Fontainebleau.

Se ha dado la lista de los embajadores que la República española envía a las naciones extranjeras. Todos son periodistas de matiz republicano y antirreligioso. Pérez de Ayala a Londres, Ortega y Gasset a Berlín, Azorín a Buenos Aires, etc. No son hombres de talla.... son poquita cosa.

Día 22. Miércoles. Siguen los decretos del Gobierno provisional en asuntos que sólo competen a las Cortes. Decreto sobre la revisión de las haciendas locales. A los militares se les exige que fidelidad a la República. La fórmula de la promesa (no juramento) es tan vaga que nosotros hemos aconsejado a todos los que nos preguntan que pueden hacerla.

El ministro de la Guerra anuncia un decreto de profunda reforma en el ejército; el de Instrucción otro de profunda reforma en la Enseñanza; el de Justicia de profunda reforma en las cuestiones religiosas; el de Hacienda de profunda reforma en la cuestión financiera. ¡Cuanta profundidad! Nos vamos hacia el fondo. Hoy en Chamartín nos hemos probado los trajes de paisano. El sastre es un cojo que no ha sacado ni uno bien hecho.

Día 23. Jueves. Ha muerto la infanta Isabel, la infanta españolísima, a las dos y 45 de la tarde. R. I. P. El pésame del gobierno republicano de Madrid puede sintetizarse en la frase que pronunció uno de los ministros ante los periodistas fríamente: No debió irse: aquí no se la odiaba. La prensa de España y del extranjero le tributa un homenaje de recuerdo a sus virtudes. Era una mujer excepcional: la religiosidad, la sencillez., la caridad y el amor a su España eran las notas propias de su carácter.

Siguen decretos y querellas contra los del antiguo régimen.

Día 24. Viernes. Se riza el mar de la calma española. El artículo del Debate habla del peligro soviético en España. La prensa extranjera se ocupa mucho de este punto. Trae el Debate del sábado 25 abril, datos muy importantes.

Una calumnia acaba de servir al Gobierno para manifestarse abiertamente hostil al dignísimo primado Cardenal Segura ${ }^{67}$. Anteayer publicaron los periódicos rabiosos de la izquierda unas palabras que el Primado había dicho. Se reducían a decir que "si la Republica triunfaba Dios maldeciría a España”. El Gobierno, es decir el ministro Fernando de los Ríos, tomó pie de eso que se decía para hacer información y poder hacer daño al Prelado. Resultó que era falso; los periódicos se retractaron, aunque de mala gana, y el Ministro, confesando que se trata de una calumnia, todavía lo hace motivo de una nota querellosa a la Santa Sede. "No por lo que haya sucedido, dijo a los periodistas, sino por considerar que es una obligación velar para que las cosas no pasen a mayores, se ha entregado esa nota". ${ }^{6}$

Se están celebrando en toda España funerales por el alma de la virtuosa infanta Isabel. Ayer en el ayuntamiento de Madrid pidió un concejal "que constara en el acta el sentimiento de la corporación por la muerte de la Infanta Isabel”. La mayoría republicana acogió con protestas de indignación la petición

${ }^{66}$ Gil Pecharromán, J. 1994: 127-128.

67 Gil Delgado, F. 2001. Pedro Segura: un cardenal de Fronteras: Madrid: Biblioteca de Autores Cristianos. Martínez Sánchez, S. 2004. Los papeles perdidos del Cardenal Segura (1880-1957): Pamplona: EUNSA.

${ }^{68}$ Cárcel Ortí, V. 2011: 249-250. Carta de Fernando de los Ríos a Tedeschini, Madrid 24-4-1931. 
y se negó. Sigue el revuelo sobre las fabulosas cantidades de dinero que tenían los Reyes. Se calumnia a la Reina en los periódicos de haber llevado consigo las joyas de la Corona de España (El valiente marqués de Loyola publica un precioso artículo en el Debate sobre esto)

Han llegado hoy a Madrid los presos de la sublevación de Jaca puestos en libertad por el Gobierno; su llegada a Madrid ha sido una espléndida manifestación comunista. ${ }^{69}$

Con motivo de alarmarse algunos papás de los niños de este colegio de Chamartín, vuelve Alcalá Zamora a reiterar su apoyo y rogar que no salgan los niños hasta dar sus exámenes. Con estas seguridades la vida del colegio es normal.

Día 25. Sábado. Sigue la campaña contra el Primado a propósito de las calumniosas palabras que le atribuyó un periódico: estas eran así: "Caiga la maldición en España si en ella arraiga la República". El ministro de Justicia que ya ha declarado que son falsas sigue dándole vueltas al asunto. Este ministro anuncia un decreto sobre la libertad de cultos. El de la Guerra anuncia otro de reforma radical en el ejército. Se decreta la sustitución de la bandera española por la bandera tricolor, roja, amarilla y morada. ${ }^{70}$ Ha causado esto mucha pena y protestas.

Día 26. Domingo. Nada de particular. La cuestión del separatismo catalán es la nota del día.

Día 27. Lunes. Siguen los decretos arbitrarios. Se habla de que en un pueblo de Huesca llamado Torralba de Aragón ha habido una aparición de la Virgen Santísima. Varias niñas jugaban en el pórtico de la iglesia, cuya puerta estaba cerrada. Cuatro niñas miraron por curiosidad por una rendija que tenía la puerta al interior de la iglesia y vieron dentro una mujer vestida de luto que tenía en sus manos un devocionario y un rosario. Avisaron a la maestra; el párroco no estaba a la sazón en el pueblo. Fueron con las niñas la maestra, un alguacil del Ayuntamiento y dos personas más, reabrieron la iglesia y nada vieron.... El pueblo se acercó entero al cundir el rumor. Se volcó a inspeccionar la iglesia. Las niñas volvieron a ver a la señora que estaba delante de una imagen del corazón de Jesús que hay en el altar mayor; los demás no la veían. Por indicación de la maestra preguntaron las niñas en la aparición que qué deseaba, y respondió: "Que no maltratéis a mi Hijo". Entonces se acordó la gente que al proclamar la República, varios hombres habían entrado en el Ayuntamiento y destrozado el crucifijo que allí había. Rompieron a llorar hombres y mujeres, y trajeron los dos crucifijos. Una de las niñas, llamada Josefa, los acercó a la señora y le dijo: "Virgen purísima, aquí tenéis a vuestro Hijo". La señora respondió: "Dejadle allí.... y desapareció". Hasta aquí el Debate. ${ }^{71}$ Una señora de Madrid, amiga nuestra, ha escrito al párroco de Torralba, don Jesús Lera, rogándole que le diga lo que haya de cierto y éste le ha contestado que la relación dada por el Debate es la historia rigurosamente exacta de lo sucedido y que se están haciendo las informaciones del caso ${ }^{72}$.

${ }^{69}$ Mendizábal Villalba, A. 1933. "El Comunismo”. La crisis moral, social y económica del mundo. Semana Social de Madrid. VII Curso de las Semanas Sociales de España: Madrid: 353-394. Hernández Figueiredo, J. R. 2010. "Avances y estado del comunismo en vísperas de la guerra civil española". Analecta Sacra Tarraconensia 83: 759-906

${ }^{70}$ Zulueta de, 1931. "La herencia. Baja la bandera tricolor". Crisol, Madrid, 23-6-1931. Arrarás, J. 1964: 83-84. Juzdado Martín, J. 1983. "La primera bandera madrileña de la segunda república se izó en el Palacio de Comunicaciones". Boletín de la Academia Iberoamericana y Filipina de Historia Postal: 142-143: 11-14.

${ }^{71}$ El Debate (1931). 29 de abril de 1931

${ }^{72}$ Christina Jr, W. A. 2011. El Reino de Cristo en la Segunda República. Una historia silenciada. Barcelona: Ariel: 413 
A propósito de casos extraordinarios en el Cerro de los Ángeles ${ }^{73}$ también pasan cosas raras. Los casos que he podido averiguar son: Primero: dos o tres días después de proclamada la República fueron en un camión varios desalmados para poner un cartel en el monumento que decía: "Viva la República" y a hacer después disparates. Al llegar ya a boca de noche, vieron a un hombre, vestido de negro con los brazos en cruz, rezando de rodillas en las gradas del monumento. Este, al sentir el ruido de los que se acercaban, volvió la cabeza y les miró. Los cobardes se llenaron de tal pánico que volvieron al camión y se volvieron precipitadamente a Madrid sin hacer nada.

Este es el hecho. La fantasía comenzó a desfigurarlo, diciendo que el P. José María Rubio, muerto el año pasado en olor de santidad, se había aparecido en el Cerro de los Ángeles, etc. ${ }^{74} \mathrm{Se}$ comenzó a averiguar quien era aquel personaje vestido de negro: creyeron que era don Fernando Baüer, el banquero judío convertido. Las carmelitas del convento del Cerro dieron con la verdad. Se trata de un señor, empleado de correos en Getafe, que para desagraviar al Corazón divino ha pasado varias noches en oración en el Cerro, luego en la misa de las Monjas, comulga y se vuelve a su casa.

Otro suceso comprobado es el de varios sacrilegios que fueron con el propósito de colocar un gorro frigio en el monumento. El encargado de ponerlo subió por unas sogas que habían puesto para el caso, y al estar a alguna altura, perdió el equilibrio y cayó. Se rompió el cráneo y por tres sitios la columna vertebral, quedando muerto. El médico que ayudó a hacerle la autopsia lo ha contado. Todo esto rodea el cerro de los Ángeles de consejas y fantasías y es el caso que hasta hoy no ha sido profanado. Solo dicen del comandante aviador Ramón Franco, el del vuelo del Plus Ultra, hombre sin fe y lleno de orgullo satánico, que pasa en su aparato (es el jefe superior de aviación) por encima de la estatua del Corazón de Jesús y suele decirle: "Veremos a ver quien puede más si Tú o yo".

Día 28. Martes. El Debate ha constituido en Madrid una organización electoral de derechas que se llama Acción Nacional. Parece que cuenta con dinero católico en abundancia, aunque no se sabe cuánto. El lema es Religión, Patria, Orden, Familia, Trabajo y Propiedad. Se propone dar mítines para preparar las candidaturas de diputados que prescindiendo de la idea monárquica se decidan a mantener el orden y las idas católicas. ${ }^{75}$ El A.B.C. ha formado otra organización con el nombre Acción Monárquica. Sus ideales son los mismos que los del Debate pero a base de la vuelta del Rey. ${ }^{76}$ Comienzan las disensiones entre ambos de los respectivos periódicos, aunque calmadas.

Corre con insistencia que el famoso comunista ruso Trotski ha pedido permiso al gobierno español para establecer su residencia en Sevilla. El caso es cierto, lo que no sabemos es si el Gobierno se atreverá a dar este paso tan vergonzoso. No parece que las naciones lo permitan.

Siguen los decretos arbitrarios, los atropellos, las profanaciones, etc a la orden del día. Decreto suprimiendo las órdenes militares de Alcántara, Calatrava, Montesa, etc, sus capellanías, sus empleados....

Decreto declarando fiesta nacional el dos de Mayo, pero que se supriman las misas que se solían celebrar este día en el obelisco de los mártires del dos de Mayo. ${ }^{77}$

${ }^{73}$ Caballero, SJ., J. 1977. Corazón de España. Historia del monumento del Cerro de los Ángeles, 19001976: Madrid: Fe Católica. .

${ }^{74}$ San José María Rubio y Peralta (1864-1929), jesuita español nacido en Dalías (Almería); conocido como el apóstol de Madrid; fallecido en Aranjuez (Madrid) en mayo de 1929 y canonizado por Juan Pablo II el cuatro de mayo de 2004.

${ }^{75}$ Arrarás. J. 1964: 95-98 y Gil Pecharromán, J. 1994: 92-101.

${ }^{76}$ Gil Pecharromán, J. 1994: 101-105

${ }^{77}$ Cárcel Ortí, V. 2011: 317. Despacho de Tedeschini a Pacelli, Madrid 6-5-1931. 
Día 29. Miércoles. Están en prisión los generales Berenguer y Mola $;^{78}$ se les sigue la causa con bastante pasión. Se decreta fiesta cívico nacional el $1^{\circ}$ de Mayo, día del obrero y tenemos tres fiestas seguidas. $1^{\circ}, 2^{\circ}$ y $3^{\circ}$ que es domingo. ¡Vengan fiestas! Está revuelta la gente honrada con la probable venida de Trostski a España, Decretos arbitrarios. El infante don Juan, hijo del Rey, el más pequeño, ha ingresado en la escuela naval inglesa de Darmouth. (Sic).

La primera enseñanza va en tren expreso a la escuela única, laica y sin Dios. Con el decreto dado por el ministro de Gracia y Justicia de la libertad de cultos coincide el de Instrucción pública por el cual se suprime la enseñanza del catecismo en las escuelas: el papá que desee que a su hijo se le enseñe el catecismo lo pedirá por escrito al maestro. Los crucifijos quedan desterrados del local de las escuelas, de las oficinas públicas, salas de ayuntamiento, etc.

He hablado con el Sr. Ferragut, comandante del Blas de Lezo, sobre la insubordinación de la dotación en Cádiz. Fue de carácter comunista; el digno comandante antes de derramar sangre o que le echasen al mar, bajó a encontrarse con el comandante de Marina de la plaza y luego ha venido a contar todo al ministro de Marina. En vez de restituirle al Blas de Lezo se le ha dejado disponible y se le ha dado una licencia de dos meses en Mahón. Disturbios, tiroteos, algaradas comunistas por las calles de Barcelona y de Bilbao. En Barcelona han matado a un guardia civil y tanto en una como en otra capital ha habido muertes y heridos. ${ }^{79}$

Jueves 30 de abril. Como cada día tiene su característica alarma, la de hoy es la preparación de la fiesta del obrero de mañana $1^{\circ}$ de Mayo. Es de lo más peregrino lo que se espera. Mañana cierre general de todo. Ni carne, ni pan, ni verduras, ni taxis, ni Bancos, ni... ni nada. Solo circularán, si pueden, el metro y los tranvías. Todo el mundo de huelga y arréglese como pueda.

Día $1^{\circ}$ de Mayo. Viernes. La fiesta del Trabajo. Han transcurrido con orden y una compostura edificantes, según el Ministro de Gobernación. Ahí va una acuarela. Desde las 10 de la mañana todo el mundo a divertirse. Quedan abiertos al público los preciosísimos y famosos sitios reales del Pardo, Campo del Moro y Casa de Campo, modelos de jardinería y de parques bien cuidados.

Yo me subo a las once de la mañana a la torre de observatorio del colegio con unos prismáticos y me recreo en el panorama. Han invadido nuestro pinar las turbas hasta quizá mil personas: llevan sartenes, garrafas de vino, provisiones, etc y encienden fogatas para preparar la comida. Han llevado un organillo, un gramófono, unas charangas y corren, comen, bailan, etc, etc. No han destrozado nada.

Los alrededores están llenos de grupos que hacen lo mismo que los del pinar. Patrullas de hombres, mujeres, chiquillos cruzan la carretera gritando Viva la República y otras cosas. Los tranvías pasan formando un racimo de carne humana de ambos sexos que vocifera como una banda de energúmenos.

Por la noche recojo las impresiones de Madrid. Ha comenzado la función con una manifestación francamente comunista, pero sin desorden. Dicen que llegarían a 45.000. Banderas rojas, letreros con "Viva Lenin", "Queremos un Gobierno como el de Rusia", "Viva el Comunismo", etc. La hoz y el martillo en la bandera.

Los tranvías y el metro no podían funcionar. Los asaltaban por completo. Las dos empresas han pedido al Gobierno la huelga para sus empleados y desde las dos de la tarde dejaron de circular también. Las olas de gente fueron a buscar por la tarde los sitios amenos: el Retiro, Rosales, las

\footnotetext{
${ }^{78}$ Iribarren, J. M. 1945. El general Mola: Madrid 1945. Vigón, J. 1957. General Mola, el Conspirador: Barcelona.

${ }^{79}$ Arrarás. J: 1964: 93.
} 
Bombillas, el Parque del Oeste, la Casa de Campo, los sitios reales. Aquí el destrozo ha sido catastrófico. Se han arrancado 36 árboles de cuajo y solo por el instinto de hacer daño. Han desaparecido todos los faisanes y conejos de la Casa de campo, que los había en abundancia tal que las bandas de faisanes dorados se levantaban a docenas y los conejos salían de entre los pies del viajero. Se han contado casos asquerosos. Un chiquillo de cinco años ha comido tanto hostigado por sus padres y por el público que ha muerto allí mismo. A una joven embarazada la han hecho abortar en presencia del público. Los pecados de la carne se cometen delante de los espectadores que quieran presenciarlos; se han bañado desnudos hombres y mujeres en los estanques y finalmente han dejado aquellos sitios tan llenos de residuos de las comilonas que si el Gobierno no toma una medida del pudrirse traerán a Madrid una epidemia. Durante esta bacanal se han perdido más de cien niños pequeños que la policía ha recogido para buscar a sus padres... Entre heridos de riñas, atacados de alcoholismo agudo se han llenado las casas de Socorro; solo en la de la del distrito de Palacio se asistieron anoche a 36 personas.

Me han dicho que en la manifestación comunista iban varios ministros. Que el palacio de la Gobernación les habló el Presidente con frases adulatorias y aceptó el pliego de proposiciones comunistas que le traían. ¡Y mañana fiesta y pasado mañana fiesta!

Día 2 de Mayo. Fiesta Cívica. Sábado. Sigue el peligro de que Trotski venga a España. Tenemos ya en España al diputado comunista francés $\mathrm{Mr}$ Dariot (sic) ${ }^{80}$ Es nombrado capitán general del ejército el general Aguilera, enemigo de la dictadura, impío, pero que está muy enfermo y dará poca guerra. ${ }^{81}$ Siguen el Debate y el $A B C$. sin entenderse: el punto en el que no concuerdan es el de la Monarquía. El día ha pasado tranquilo en Madrid.

Lunes 3 de Mayo. Domingo. Sin novedad. Descanso de tres días de fiesta. Madrid presenta su aspecto ordinario.

Lunes 4 de Mayo. Los militares están deshechos. Se quiere que solo queden los Generales, Jefes y Oficiales, adeptos al régimen. Se les ha propuesto por el ministro de la Guerra el que pidan el retiro cuantos lo deseen con el sueldo íntegro, de suerte que los que no lo pidan queden a merced del Ministro que les obligará a retirarse en las peores condiciones.

Se ha dado el decreto sobre las elecciones: han protestado todos los periódicos de la derecha. Se nombra un diputado por cada 50.000 habitantes. Cada fracción que suba de 40.000 se tendrá en cuenta en la provincia que sólo tenga 5 diputados (se sumarán a los candidatos del Gobierno hablado en plata). Cada provincia formará una sola circunscripción excepto Barcelona, Madrid que formarán circunscripciones aparte. Pueden ser elegidos diputados los sacerdotes y las mujeres. ${ }^{82}$ La edad de votar es la de 23 años (para sumarse los estudiantes de la F.U.E y otros alborotadores mocosos)

Sigue el Debate con su Acción Nacional y el $A B C$ con su Acción Monárquica. En el fondo se entienden y no se estorbarán. Siguen los decretos; siguen las colocaciones de gentes de izquierdas en todos los puestos y el derrumbamiento de la gente de las derechas con inicuas sustituciones. Disturbios en la zona española de África. Los periódicos extranjeros siguen dando la voz de alarma sobre la

${ }^{80}$ Doriot, J. (1898-1945). Metalúrgico y diputado desde 1924 por la localidad de Saint-Denis. Opuesto a la intervención francesa en el Rif e impulsor de la creación de un Frente Popular en Francia y Europa.

${ }^{81}$ Aguilera Egea, F. Nació en Ciudad Real. Militar de carrera; opuesto a la Dictadura de Primo de Rivera; encabezó "la sanjuanada" (1926) y la llamada conspiración de los artilleros (1929). Moría, efectivamente, en 1931.

82 Pérez de Ayala, R. 1931. "Las mujeres harán la nueva España”: El Socialista. Madrid 18-7-1931. Carreras de, F., 1983. "Los intentos de reforma electoral en la segunda república española": Revista de Estudios Politicos: 165-197 
propaganda comunista y soviética en España: se nos están llenando las ciudades y sobre todo los puertos de mar de agentes soviéticos.

Es inicua la arbitrariedad del Gobierno con los concejales que han salido en los Ayuntamientos contrarios a las ideas comunistas que él ampara. Después de unas elecciones, rabiosamente legales, el Gobierno republicano intenta barrer a todos los concejales de derechas ya proclamados y en uso de sus cargos. Las comisiones gestoras funcionan en casi todos los ayuntamientos de España donde han sacado mayoría o casi mayoría los partidos de derecha. El sistema es sencillo. Se formula una denuncia, una protesta por cualquier concejal republicano y.... ¡zás! Las elecciones han sido ilegales, comisión gestora para anular las elecciones y preparar otras nuevas que será en Junio. 20 municipios de Navarra, donde han triunfado derechas, tienen ya comisión gestora, incluso en Pamplona. ¡Qué gentecita!

El acontecimiento del día ha sido la pastoral del Primado. El cardenal Segura hace días se ausentó de Toledo y no se sabía donde estaba. La persecución contra él ha venido atizándose en los periódicos de la izquierda. Por fin se supo no oficialmente que estaba en la Ciudad Lineal aquí en Madrid. Los periódicos de hoy publican el documento más respetuoso, más documentado, más valiente y más claro al dar sus normas que se ha publicado hasta hoy por los Prelados. Han salido ya varias cartas pastorales de prelados, que no quiero citar, porque es mejor para ellos: tímidas, anodinas, aconsejando por todos los tonos la sumisión al Régimen como doctrina de Cristo, pero el espíritu se agobia, al ver que nada dicen de las profanaciones que se han hecho, de los escándalos que hemos presenciado, de las leyes de libertad de culto, de enseñanza laica, etc. La pastoral del Primado levanta el alma: nos dice que hay que luchar contra el mal (Véase en el Debate o Siglo Futuro, La Nación, $A B C)$. Ha causado un revuelo grande. ¡Gracias a Dios que los Prelados dan la voz de alerta! ${ }^{83}$

Los embajadores nombrados por la República resultan..... deficientes. El doctor Marañón no va a París; dicen que ha renunciado, otros dicen que Francia no lo acepta; al del Quirinal Gonzalo Figueroa le pasa lo mismo. ${ }^{84}$ Para el Vaticano se ha nombrado a D. Luis Zulueta, masón y ateo. ${ }^{85}$

Martes 5. Sigue el revuelo por la pastoral del Primado; siguen las protestas contra el decreto sobre la forma de elecciones de diputados. Siguen robos, sacrilegios, huelgas, desilusiones de hombres de la derecha. No hay porque insistir.

Miércoles 6 de Mayo. El Primado no está en Madrid ni en Toledo. Al Ministro de Justicia le pica mucho la banderilla de la pastoral del Primado: se quejará a Roma. Las noticias particulares acusan más inmigración soviética en España. Siguen las quejas de los diarios contra el decreto de elecciones.

Jueves 7 de Mayo. Sigue la indignación del Ministro de Justicia contra la belicosidad del escrito del Primado. $A B C$ y el Debate discuten sobre el programa que hay que adoptar si a base de Monarquía o no. Ambas Acciones Monárquica y Nacional se desenvuelven con calor. El Gobierno se sabe que no pasa por la Monárquica y quiere suprimirla a todo trance. Los artículos del $A B C$ le escuecen mucho.

${ }^{83}$ La Carta Pastoral que tanta polémica suscitó está fechada el 1 de mayo de 1931. Sobre el particular: Cárcel Ortí, V. 2011: 312-313, 322-323 y 328-331. Carta de Segura a Pío XI, Toledo 6-5-1931; carta de De los Ríos a Tedeschini, Madrid 7-5-1931 y despacho de Tedeschini a Pacelli, Madrid 8-5-1931.

${ }^{84}$ Figueroa y Torres, Gonzalo, hermano del Conde de Romanones, fue alcalde de Madrid entre diciembre de 1904 y junio de 1905.

${ }^{85}$ Zulueta y Escolano, L. (1878-1964). Durante la República fue Ministro de Estado y embajador de España en Berlín y en el Vaticano. ZULUETA, L. "El ideal en la educación. Ensayos pedagógicos y otros textos", edición de ROBLES SANJUÁN, V. 2006: Madrid 
Flota en el ambiente no sé qué pesadez que nos tiene a todos con un espíritu de pesimismo atroz. Nadie se mueve, todos comentan la situación y se limitan a deplorarla. Me he trasladado a vivir a la Casa Profesa para tener datos y escribir un folleto acerca de la caridad que las personas dirigidas por los jesuitas despliegan en Madrid. Tendrá dos partes: una la Enseñanza; otra la caridad corporal y espiritual. Veo que los padres de la profesa están como aplanados por el pesimismo y auguran días muy tristes de persecución. En varias ocasiones algunos han ido a dormir en casas particulares; todos tienen traje de paisano. Los de los padres de Chamartín no los han probado y el sastre se los ha vuelto a llevar para corregir sus defectos. ${ }^{86}$ Anoche bajé al Círculo de los caballeros del Pilar. Me ha dado una pena horrible. Abogados, magistrados, generales, médicos, en fin gente influyente. Todos lamentando lo que pasa y sin decir que ellos hayan tomado medida alguna para resistir. Me ha hecho una impresión muy rara el estado de ánimo de estos hombres. ${ }^{87}$ El Comandante de Marina, don Guillermo Ferragut, ha contado la sublevación de la marinería en su barco el Blas de Lezo. Todos coinciden en que es un atropello y se despiden..... con lamentaciones. Aquí hay algo, es una losa de plomo que nos aplasta. De provincias vienen noticias de robos, de huelgas, de chispazos comunistas. Sevilla es un horno de malquerencias. Véanse los periódicos de estos días. Esto es un infierno. No se puede vivir así. Yo he hecho conducir en un camión del Colegio todos mis apuntes y papeles a casa de mi hermana. No creo de ningún otro que haya tenido esta precaución y eso de que a mí me tildan de excesivamente pesimista. El P. Rector de Chamartín también está enviando a casas particulares las joyas, ornamentos, custodias, cuadros, etc de valor. No sé que en otras residencias se tomen estas precauciones.

Viernes 8 de Mayo. El revuelo causado por la hermosa pastoral del Primado crece en el ministerio y en los infames periódicos de la izquierda. El clero de Toledo se ha puesto a la defensa y devoción de su Prelado. El ministro de Justicia sigue disparatando sobre la cabezonería de ese hombre inculto, soberbio.... Sabemos que algo trama en desquite. Siguen los crímenes. El párroco de Villalafuente (León) asesinado porque sí..... ${ }^{88} \mathrm{Se}$ ha revocado el proceso contra Berenguer. Todos veíamos que se trataba de una pantomima. Las dotaciones del Jaime $1^{\circ}$ y del apostadero de Cartagena se han medio sublevado con sesgo comunista. Otro decreto suprimiendo los patronos del ejército: la Inmaculada en Infantería, Santa Bárbara en artillería, Virgen del Carmen en Marina, Santa Teresa en Administración Militar. Varios ayuntamientos deciden que no haya procesión del Corpus.

Esta mañana y mañana son los destinados para inscribirse en el censo electoral los no incluidos que tengan derecho a ello. Yo lo he hecho y casi todos los padres. Se han inscrito hoy unos 4000 injustamente borrados que no pudimos votar en las elecciones municipales.

Sábado 9 de Mayo. Se presenta la querella contra el Gobierno de la Dictadura: se quiere llevar a los Tribunales a todos los que en ella intervinieron para que den cuenta de sus actos. Para mañana se presienten disturbios.

Se nos ha dado por tercera vez en Chamartín toda clase de garantías por parte del Gobierno. Ha dicho Alcalá Zamora que no tenemos porqué alarmarnos: "que si hay algún sitio en España donde no hay peligro ninguno de ser asaltados es Chamartín de la Rosa y que así se lo ha comunicado a las Madres reparadoras".

\section{${ }^{86}$ Verdoy, A: 65-66}

${ }^{87}$ El Círculo de los Caballeros del Pilar era una de las Congregaciones Marianas, ubicadas en la Residencia de la Calle de la Flor, que agrupa a la flor y nata de la aristocracia católica madrileña. Su director y alma máter era el Padre Alfonso Torres (1879-1946).

${ }^{88}$ Efectivamente el 1 de mayo de 1931 fue asesinado en la localidad de Villalafuente, provincia de Palencia y diócesis de León, su anciano párroco, contaba a la sazón ochenta años, Sotero de Diego. Santos y Pastor, A. 1932. Proceso por asesinato del párroco de Villalafuente: Palencia 1932. 
Domingo 10 de Mayo. Paso el día en la residencia de la Flor, la Profesa. He concluido mis apuntes para el folleto de la caridad con el pobre que despliegan los nuestros en Madrid ${ }^{89}$ y me volveré esta tarde a Chamartín. Como en la Flor: todo está tranquilo, pero dominado por el pesimismo más negro. Al volver a Chamartín hacia las cinco de la tarde me encuentro con que en la Plaza de la Cibeles están varios piquetes de la guardia civil a caballo y camiones con tropa. La calle de Alcalá desde la Cibeles a Independencia ataponada de gente; dos autos destrozados se ven muy bien desde la camioneta que he tomado. Grupos de obreros, estudiantes y jovenzuelas por toda la Castellana hasta Colon en actitud hostil; cerca del edificio del $A B C$ traen a un joven las turbas insultándole. Me dicen que han asesinado al joven José Ignacio Luca de Tena, director del ABC. ${ }^{90}$ En Chamartín me entero de todo. Por la mañana ha sido la Junta de Acción Monárquica que tiene su local en la calle de Alcalá. Se han juntado hacia las 11 un numeroso núcleo de monárquicos con un delegado del Gobierno. Se ha simulado por el elemento comunista de la Casa del pueblo una manifestación monárquica imaginaria y allí han acudido más de un millar de hombres para linchar a los monárquicos, que desde el centro han pedido protección al Gobierno. ${ }^{91}$ Este les ha enviado un camión blindado; el cual se ha puesto en medio de la calle para que los monárquicos que querían salir tengan que caer en manos de la turba que está entre el camión y la puerta. Por fin han asaltado el camión; el conductor ha huido; no ha habido quien les defienda y ha medio matado a un tal Santander, a un Pombo y a otros que han sacado del camión tirándoles de los pies hacia fuera. Han quemado dos autos, uno el del marqués de Luca de Tena, y la han emprendido camino de la casa de $A B C$. Han forzado las puertas y allí han cometido destrozos. El Sr. Luca de Tena no estaba allí. Estaba en el local de la Acción Monárquica. Por fin las fuerzas de la Guardia civil han disuelto los grupos.

La esperanza que tenemos nosotros de defensa que la Guardia Civil se ha visto esta tarde, porque se ha visto que tienen órdenes de dejar hacer.

Hoy se ha vuelto a meter en prisiones al general Berenguer y se ha dictado auto de prisión contra todos los ministros de la Dictadura. Dios nos asista. Están en prisiones el General don Dámaso Berenguer, el doctor Albiñana, jefe de La Legión antirrepublicana, el almirante Cornejo, el ministro de Marina durante la dictadura y don Galo Ponte, ministro de Justicia. ${ }^{92}$

Lunes 11 de Mayo. Uno de los días más nefandos de la historia contemporánea. ${ }^{93}$ Ayer volví a Chamartín. Comenzó el día de un modo ordinario, comentándose los tristes sucesos de ayer con la quema de dos autos, con las prisiones de tantas personas inocentes y honradas con el asalto al ABC.

${ }^{89}$ Posiblemente se esté refiriendo Risco al folleto titulado La Compañía de Jesús en España 1931-1938, Madrid 1938, texto que apareció años más tarde sin firma de autor. Por estos mismos años se publicaron libros con títulos parecidos: Calvo, R. 1931. Labor de los jesuitas españoles: Valladolid; Mantilla, S. 1930. Un jesuita en las minas. El padre Juan Manuel de Obeso en la zona minera de Vizcaya: Valladolid; Marín, C. 1933. Círculo Católico de Obreros de Burgos. Cincuenta años de Acción Social Católica: Burgos.

${ }^{90}$ Luca de Tena, J. I. 1991 y 1991. Mis amigos muertos: Barcelona 1975 y Papeles para la pequeña y la gran historia. Memorias de mi padre y mías Barcelona.

${ }^{91}$ Plá, J. 1933: 63-66. Pla revive de manera muy parecida al padre Risco los sucesos de la tarde noche del 10 de mayo, acecidos en la Puerta del Sol. Todo un presagio de lo que sucedería al día siguiente. Verdoy, A. 1995: 67-75. Hernández Figueiredo, J. R. 2003. “Anticlericalismo incendiario en el comienzo de la II República española (11-13 de mayo de 1931), a la luz de los informes inéditos vaticanos" (11-13 de mayo de 1931), a la luz de los informes inéditos vaticanos, Antologia Annua, 50: 243-310.

92 Ponte; G. (1867-1943), jurista aragonés, especializado en Derecho Foral Aragonés. Presidente de la Audiencia de Cádiz y ministro de Justicia en el Gabinete Civil de Primo de Rivera (1925).

${ }^{93}$ Cárcel Ortí, V. 2011: 344-350. Despachos de Tedeschini a Pacelli, Madrid 15 -5-1931. Narbona, F. 1954. La quema de los conventos: Madrid: Publicaciones Españolas. 
Son las once de la mañana: los niños del colegio están en sus clases. Son 230 internos y unos 20 externos. Ayer corrió la noticia de que habían incendiado la iglesia nuestra de Málaga ${ }^{94}$ y esperábamos la venida del Debate para ver si era cierto. Viene un caballero de Madrid muy alarmado que quiere hablar con el P. Rector. Yo estaba en la portería y me da la noticia. Nuestra residencia de la Flor está ardiendo. ${ }^{95}$ Se ha dado la orden entre los comunistas y se ha dado en pública Puerta del Sol anoche la orden de hoy. A las 10 y media se quemaría la Flor, a las 11 y media nuestro colegio de Areneros; a las 3 y media el Colegio de las Maravillas de los Hermanos de las Doctrinas Cristianas y a las seis de la tarde el colegio de los jesuitas de Chamartín. Se ha dado a los incendiarios una lista de los colegios, conventos e iglesias que tienen que quedar hoy en los cimientos a poder de las llamas. ${ }^{96}$

El teléfono nos avisa por varios conductos que la iglesia de la Flor está ardiendo y que los incendiarios se dirigen en tropel al colegio de Arenero Areneros; ${ }^{97}$ que la iglesia que acaban de levantar los padres carmelitas en la plaza de España está ardiendo ya.

El padre rector, Enrique Jiménez, da muestras de grande serenidad. Avisa por teléfono a todas las familias que viven en Madrid y tienen niños internos en el Colegio para que vengan por ellos y se lleven algunos otros de los que viven fuera de Madrid. Avisa al cuartel de la Guardia Civil pidiendo fuerzas: le ofrecen seis parejas, ruega que manden más.

Yo a las 12 subí a la torre del observatorio del colegio; con mis prismáticos se veían perfectamente las llamas de cuatro hogueras cuyo humo subía a las nubes. Los trabajadores de las fincas vecinas habían interrumpido sus trabajos: apenas circulaba gente por la carretera. A todo esto, nuestros trajes de paisano estaban aún en la sastrería y el camión del colegio había ido a toda prisa por ellos. Yo tenía en mi cuarto la camisa, el cuello, la corbata; nada más. (Siguen cuatro líneas tachadas)

Después de comer, se desarrolló una actividad pasmosa en el colegio. El camión trasportaba las cosas de valor que aún no se habían sacado fuera. Un hermoso cuadro del Greco evaluado en más de 20.000 duros; un retrato de una princesa de Salm Salm, atribuidos a Goya; cálices, alhajas de la iglesia; un Niño Jesús de Montañés, etc, etc. Habían venido los trajes de paisano, pero incompletamente. Yo tuve que coger un sombrero viejo que halle en el suelo; otros no hallaban los pantalones; en fin, algo de confusión. El P. Alegre no pudo vestirse de seglar. ${ }^{98}$ La Guardia civil comenzaba a venir y circulaba por todo el colegio y jardines. Las familias amigas que venían para llevarse uno, dos o más internos a sus casas y enviarlos en el tren a sus padres. Todo daba al colegio un aspecto animado y fantástico. Yo me sentía con una paz imperturbable; lo veía todo con ojos de artista; era un cuadro que no carecía de sublimidad.

Llamé a Tomasito Calles, vecino del Colegio y de toda confianza y con tres criados hice trasladar a su casa todo lo que quedaba en mi cuarto y no quería perder. El incendio del colegio era cosa descartada aquella tarde.

94 Cárcel Ortí, V. 2011: 387-390. Despacho de Tedeschini a Pacelli, Madrid, 21-5-1931 que contiene una nota firmada por un testigo ocular sobre los sucesos de Málaga. Nadal Sánchez, A. 1986. La República en Málaga: Diputación Provincial.

${ }_{95}$ Plá, J. 1933: 66-68. El periodista catalán fue testigo lejano, pero testigo del incendio, lo vio desde la azotea de la pensión en la que se alojaba. Su descripción humorista, esconde dolor, pena y preocupación. Cárcel Ortí, V. 2011: 361-362.

${ }^{96}$ Hernández Figueiredo, J. R. 2003: 349-359.

${ }^{97}$ Cárcel Ortí, V. 2011: 362-364. Carta de Mosquera a Tedeschini, Madrid 16-5-1931.

${ }^{98}$ El Padre J. Alegre nació en Cartagena (Murcia) en 1865. Era en ese momento Ministro o encargado del mantenimiento y jefe del personal del Colegio del Recuerdo. Murió asesinado en Madrid el 10 de noviembre de 1936. 
Vino el criado de la portería a darme un recado que me disgustó un poco. Mi hermana María acababa de decir por teléfono que la esperase porque vendría por mí con un auto. Yo había quedado de días atrás en que, si había peligro, iría a su casa a refugiarme. Este plan tenía un peligro. Los porteros de la casa donde vive mi hermana, que habían logrado ese cargo por recomendación de las Esclavas del Sagrado Corazón, se han mostrado desde el principio republicanos muy exaltados. Al recibir este aviso tan raro de que la esperase, temí que mi hermana no creyese seguro el asilo de su piso y determiné esperarle.

Tomé los prismáticos y me subí otra vez a la torre. El espectáculo que se me presentó a mi vista no se me borrará nunca. Nuestro colegio, en especial la torre, domina todo Madrid a vista de pájaro y se precisan todos los sitios y edificios principales. Iba conmigo uno de los pequeñines del Sr. Drake, nieto del Conde de la Cortina. En la extensión que abarcaba el casco de Madrid contamos nueve hogueras. El incendio de la iglesia de la Flor había tomado tales proporciones que a mi juicio estaba ardiendo la manzana entera hasta la plaza de Santo Domingo. Más a la derecha ardía el convento de carmelitas de la Plaza de España. Entre ambos incendios se veía otra columna negra muy elevada, haciendo de fondo de Madrid. Venía el incendio del colegio de Areneros, ancho, muy negro, y con una humareda que cubría todos los alrededores: dos incendios más a la derecha de menores proporciones. Al extremo opuesto en Cuatro Caminos, era un horror como subían las llamas del colegio de las Maravillas donde se educan cerca de 2000 hijos de obreros y al lado comenzaba el incendio de las monjitas bernardas. Con los prismáticos se veía la gente impidiendo la obra de los bomberos; subiendo a los tejados para dar fuego al ala de detrás, y ví claramente el derrumbe del ala delantera.

Me detuve aquí tiempo: detrás de Madrid se alzaba, blanco, como una aparición de paz el monumento del cerro de los Ángeles; recé con todo fervor un credo y ofrecí ante la ara de ese altar las víctimas humanas que tal vez se estaban sacrificando como desagravio cruento por los pecados de España. Bajé y en el vestíbulo de la capilla me encontré con el sargento de la Guardia Civil; había mucho aparato de tropa por los tránsitos y el jardín. Pregunté al sargento:

- Dígame: ¿está bien defendido esto?

- $\quad$ Sí, señor, descuide que no tocarán a nadie al pelo de la ropa.

- Bien, pero el edificio, ¿lo lograrán quemar?

- $\quad$ Eso.... no creo; pero tantos podían venir..... Yo quisiera ver las puertas de salida que tiene el Colegio para colocar la gente.

- Venga conmigo y lo verá

- $\quad$ En esto se nos acercaron unos seis muchachos, antiguos alumnos del colegio, que venían dispuestos a defendernos y me pidieron órdenes. Estando allí la Guardia civil su cooperación eran inútil. Vinieron conmigo acompañado al sargento y dos números, que cerraron unas puertas de salida, abrieron otras y decía el sargento: por tal otra.

- $\quad$ Si atacan por este patio y no pueden defenderse los guardias, entrarán por otra esta puerta o

En fin, yo creí que en el Colegio no entraría ni una rata. Eran las cinco y media. Se había declarado en Madrid el estado de guerra, por el cual nos creíamos defendidos. Sin embargo, todos los padres habían salido ya. Quedaban el P. Rector, el P. Alegre y algún que otro padre y hermanos coadjutores. Mi hermana no venía. Grupos de gente de ambos sexos iban estacionándose en los alrededores de ambos colegios, el nuestro y el de las madres del Sagrado Corazón. Los antiguos 
alumnos que habían venido a defendernos no me dejaban un momento; estaban dispuestos a luchar. La guardia civil había aumentado. Me dijeron que había 50 parejas de a caballo.

Son las seis y minutos: el rumor de la turba que viene por la carretera de Tetuán se deja oír y se perciben los mueras a los frailes. Varias parejas de la Guardia civil nos empiezan a empujar hacia fuera del Colegio gritando. ¡Fuera! ¡Todos fuera! y se mezcla con varios gritos de varios hombres que gritan desde fuera: ¡Ahí vienen! ¡Ahí vienen ya! En efecto el ruido extraño de los incendiarios se percibe como el del mar lejano en tormenta. Dicen que viene más de mil.

Salimos empujados por la Guardia civil y veo la cantidad de curiosos que se ha estacionado por los alrededores de los dos colegios para presenciar ávidos el espectáculo. Y no es gente del pueblo bajo. Son hombres y mujeres bastante bien vestidos. La Guardia civil se obstina en disipar los grupos y estos se disuelven aquí para formarse de nuevo allá.

Veo que los cinco antiguos alumnos se desconciertan: unos quieren quedarse en el colegio creyéndose seguros al amparo de la Guardia civil; otros quieren bajar al pueblo para tomar el tranvía del Hipódromo. Yo veo peligrosas las dos opciones. El gentío de incendiarios sube ya para el colegio y ha tomado las dos carreteras. Se me ocurre una solución y la ordeno a todos pero en voz baja; estamos ya cercados y metidos entre los grupos comunistas. Dividido en dos grupitos nos dirigimos al Pinar por la carretera que sale de la puerta de los carros. La carretera está llena de gente, pero no nos extrañan nada. Solo al cruzar la carretera de Alcobendas se nos acerca un grupo de mozos bien vestidos; son probablemente estudiantes de la FUE que son el alma de estos incendios. Yo digo en voz baja a los dos grupos que no miren para atrás y que sigan. Dos de los mozalbetes nos siguen de lejos. Entramos en el pinar y quedamos libres y dueños del campo. ¡Adiós precioso, lindo pinar! ¡Quizás para siempre!

Salimos por el Colegio de huérfanos de la Armada y nos hallamos en la Ciudad Lineal, por donde pasa el tranvía de la Ventas. Viene con nosotros el hermano enfermero, Rascón. ${ }^{99}$ Los dos grupos tomamos distintos tranvías.

Yo, que voy con Fernando Bustamante y dos más, expongo a éste mi situación. Mi hermana no ha venido por mí; yo no sé si en el ir a mi casa habrá peligro. El me contesta resueltamente que tengo que ir a su casa. Yo conozco muy bien a toda la familia. Tiene oratorio. Acepto agradecido mientras mi hermana no resuelva. Vamos aún por la mitad del trayecto, y los del tranvía comienzan a mirar al campo y a exclamar: “¡Mira! ¡Mira!” El colegio de las monjas de Chamartín está ardiendo. Mira, el de los jesuitas está ardiendo también. Miro hacia aquel lado: el colegio noviciado de las madres del Sagrado Corazón es ya una columna negra y ancha que sube hasta el cielo. Por una de las alas de nuestro colegio sube una columna de humo blanco, pequeña. Le rezo una salve a la Virgen del Recuerdo, titular del Colegio. El resto del viaje se hace felizmente. En Ventas tomamos el metro hasta Cibeles, aquí un tranvía que nos deja en la puerta de los Bustamantes, Castellana 11. La familia me recibe con intenso cariño y me dicen que no me dejarán salir de allí; que les diré misa diariamente y comulgarán todos en casa en vez de ir a la iglesia....

Paso un aviso a mi hermana y viene enseguida. El aviso del teléfono que me dio lo había interpretado mal el hermano portero. Ella dijo: "Díganle a mi hermano que se venga enseguida a casa y si no me iré a buscarle yo". El hermano le contestó: "Mejor es que venga usted" y cortó. Mi pobre hermana estaba pendiente de si me habían dado bien el recado, porque yo lo hubiese entendido; pero el portero me dijo: "De parte de su hermana, que no salga porque vendrá a buscarle en un auto" y por eso esperé hasta el último momento. Mi hermana al ver que yo no me presentaba en su casa, emprendió el

${ }^{99}$ El hermano Juan Rascón era uno de los enfermeros de la Comunidad del Colegio del Recuerdo. Nació en la localidad de Solle (León) en 1875; morirá en Madrid el año 1963. 
camino de Chamartín en un auto a las cinco y media. Se encontró la turba de más de mil personas en la plaza del pueblo de Chamartín y a un hombre bajo, gordo, que le dijeron era el alcalde de Madrid, señor Rico, el cual vociferaba a las turbas así: "Pueblo soberano, ahí tenéis esas dos casas, vuestras son; es preciso que toméis venganza de los ricos que os engañan, que son esos que viven ahí. ¿Queréis incendiarlos? Pegadle fuego, todo es vuestro; llegó el día de la justicia; pero no manchéis vuestras manos honradas con sangre humana; respetad sus vidas; todo lo demás es vuestro".

Preguntó mi hermana a un Guardia civil si podría llegar hasta el colegio y él le respondió que no; que las turbas estaban ya dueñas de ambos edificios, pero que tenían órdenes de respetar las vidas. Cuando se volvió mi hermana, el noviciado de las madres del Sagrado Corazón es un volcán en llamas. En el cementerio del noviciado está enterrada nuestra hermana Carmencita, religiosa del Sagrado Corazón que murió santamente ha dos años.

Determinamos que es mejor que me quede en casa de los Bustamantes, pues no se fía de los porteros de casa. Por la noche vienen los comentarios de la jornada de hoy. Han ardido la Flor, Areneros, los Carmelitas, los Maravillas, el noviciado del Sagrado Corazón, las monjas llamadas las Vallecas al lado de nuestra casa profesa de la Flor, el colegio de salesianos de la calle de Vallamil, (tal vez sea Villamil), el de los escolapios de la calle de Torrijos, el colegio de las Mercedarias cerca del de Maravillas. Se habla y se da por cierto que del colegio de Chamartín nuestro no han quedado más que las ruinas. Con toda esta incertidumbre paso la noche. También en la casa de los Bustamantes están intranquilos por la persecución a la Acción Monárquica. A Luca de Tena el director del $A B C$ le han encarcelado. Ha quedado suspendida la publicación del Debate.

Yo también me apeno por la suerte que han corrido los otros padres. Se sabe que ninguno ha muerto pero.... se cuentan horrores de algunos de ellos.

Martes 12 de Mayo. En casa de don Felipe Bustamante. Les digo la misa a las 9. Van viniendo noticias de los nuestros y de sus peripecias, que dejaré para cuando pueda comprobarlas. Se nos ocurre a los Bustamante y a mí ir a ver Chamartín y así lo hacemos. Está rodeado de tropa al mando de un teniente coronel que reside en el cuartel de la Guardia Civil de la plaza del pueblo. Hay que pedirle permiso para entrar. Se lo pedimos y lo da por escrito. Entramos. ¡Dios mío que desolación! La portería destrozada y medio quemada al cortar los cables eléctricos. El tránsito de la sala de visitas y la sala sin un mueble sano. Colchones, ropas, sillas, utensilios de cocina, todo revuelto por el suelo. Los cuadros apuñalados. El saloncito del P. Rector con todo revuelto. A la estatua del la Virgen del Recuerdo le han quitado la corona y el Niño a quién han cortado la cabeza. La capilla del colegio es una lástima verla. El armonium está hecho añicos: la estatua de San Luis está serrada por medio; el S. Estanislao roto en el suelo y $\sin \mathrm{Niño} ;{ }^{100}$ el precioso Crucificado de talla y de tamaño natural que acaba de regalar el Sr. Granda le han serrado los brazos; al San Ignacio del P. Salmón ${ }^{101}$ le han dejado caer al suelo y se ha roto la bandera del AMDG. Él está intacto. San José destrozado: casi todas son estatuas de tamaño natural, hechas creo por Flotat. Han arrancado la puerta del sagrario que estaba vacío con una palanqueta y está en el suelo; es de plata repujada con piedras preciosas, obra de Granda; los ornamentos, casullas, cálices, reliquias, todo esparcido y revuelto por el suelo de la iglesia, la sacristía y los tránsitos. Clavada en una de las grandes arañas del techo hay una silla. Y sobre este cuadro de

${ }^{100}$ Las imágenes de San Estanislao de Kostka y de San Luis Gonzaga, ambos jesuitas, fallecidos en plena juventud y muy pronto canonizados, eran los patronos de sus juventudes y los titulares de las Congregaciones Marianas de jóvenes adolescentes, los Estanislaos, y universitarios, los populares Luises. Verdoy, A. 2010: "La Confederación Nacional Española de las Congregaciones Marianas o la movilización de la juventud de la Virgen (1919-1923)". Estudios Eclesiásticos (85): 547-543.

${ }^{101}$ El Padre Victoriano Salmón nació en Madrid en 1863; morirá en Almería en 1910. 
desolación, aparece esbelta, majestuosa, intacta la estatua colosal de la Virgen del Recuerdo a quien no han tocado. ${ }^{102}$ Salimos pisando por los tránsitos destrozos y más destrozos y vamos a mi aposento que está en el piso bajo. No se han llevado nada; pero todo lo han revuelto por el suelo: la cama y la mesa patas arriba, los dos estantes volcados y los libros y papeles dispersos por el suelo. He tenido la triste publicidad de que lo hayan retratado los fotógrafos del diario gráfico Ahora y aquí está. (Viene una foto pegada).

En frente de mi cuarto, en el tránsito del piso bajo el panorama es el que expresa esta foto (viene otra foto a continuación). De este modo está todo el colegio: los pianos y las máquinas y sillas del salón de odontología y otras cosas las han tirado por las ventanas y quemado en la plazoleta de entrada delante mismo de la Guardia Civil y esta era la columna de humo que ví la tarde anterior desde el tranvía de las Ventas. En la ropería habían dejado todo lo que los asaltantes llevaban, camisetas llenas de piojos, (los ví), chaquetas y pantalones llenos de remiendos, calzoncillos llenos de..... otra cosa, alpargatas rotas y se habían vestido de nuevo con la ropa de los colegiales. Nos contó el sargento de la Guardia Civil que él sorprendió a uno con tres ternos puestos. En el Colegio ví al P. Rector y a varios hermanos coadjutores.

Por la noche en casa de los Bustamantes comenzaron a venir noticias de los incendios de casas religiosas e iglesias en el resto de España. Son más de cien las casas quemadas. ${ }^{103}$

Esta noche traían los periódicos el decreto de querella contra el rey Alfonso XIII y otro decretando la incautación de todos sus bienes privados. Madrid presentaba un aspecto muy triste; parece que les remuerde colectivamente la conciencia por los crímenes de ayer.

Vinieron varias personas a ofrecerme sus casas. El Gobierno ha suspendido la publicación de $A B C$ y del Debate; por el contrario van saliendo nuevos periódicos radicales: El Crisol está haciendo mucho daño.

13 de Mayo. Miércoles. He vuelto a Chamartín y me he traído algunas cosas mías. El colegio de las Madres del Sagrado Corazón está en solos los cimientos y acordonado de tropa, que no dejan entrar. He aquí el aspecto del patio. (Viene una foto grande).

Empiezo a saber la suerte de nuestras casas y de nuestros padres y hermanos. A las diez y media de la mañana del lunes nuestra iglesia y residencia de la Flor seguía su vida normal. En la iglesia donde estaban muchos fieles oyendo misa, se dio la voz del incendio que comenzaba y los fieles por orden salieron por la puerta de la residencia que da a la calle de Isabel la Católica. Un grupo de muchachos de once a doce años por parte de la Gran Vía habían comenzado a quemar unas empalizadas que separaban de la calle el solar que da a San Bernardo. Poco a poco el núcleo se hizo mayor, rodeó la residencia y en medio de un gentío que les animaba y aplaudía fueron quemando puertas y ventanas en presencia de la guardia civil que presenciaba a pie firme el espectáculo. El incendió tomo incremento y ardió casa, iglesia, círculo de los caballeros del Pilar, biblioteca, todo. A los bomberos se les impedía el usar de las bombas para extinguir el fuego. (Testimonio fotográfico).

Entre tanto algunos padres o no estaban en la residencia o pudieron salir enseguida vestidos de paisanos. La casi totalidad estaba dentro. Por una comunicación interior que la residencia tiene con la

\footnotetext{
${ }^{102}$ Patrona y titular del Colegio de su nombre; muy querida por padres de alumnos y alumnos y famosa por la famosa poesía del Padre Alarcón que comienza: "Dulcísimo recuerdo

${ }^{103}$ Hernández Figueiredo, J. R. 2003: “Anticlericalismo incendiario..." 260-295. En estas páginas se nos ofrece abundante información sobre los destrozos sufridos por edificios y casas religiosas en Málaga, Cádiz, Sevilla, Granada, Cartagena, Orihuela y Valencia.
} 
imprenta del Apostolado ${ }^{104}$ a la calle de San Bernardo quisieron ponerse en salvo. Era tarde. La salida estaba tomada. Los que iban saliendo, el P. Alarcón, ${ }^{105}$ Panizo, ${ }^{106}$ Sauras ${ }^{107}$ y otros eran acometidos por las turbas, pero escaparon. Al padre prepósito Alfonso Torres le acometieron más fuerte. ${ }^{108}$ Dicen que tenían permiso para asesinarle. Le robaron la cartera con 26.000 pesetas; las pudo recuperar, pero faltaban ya 10.000. Por fin subió a una casa por la escalera y tocó a un piso de un amigo suyo, pero no se le quiso recibir; se subió a las boardillas y a las tres o cuatro de la tarde pudo bajar amparado por unos guardias que le llevaron a la Comisaría y de ahí a una casa amiga.

Entre tanto once entre padres y coadjutores quedaban en el sótano. Hacia las cuatro de la tarde la chusma entró por fin; uno que la capitaneaba se compadeció de ellos y prohibió que se les maltratara y llamó a la Guardia Civil que en un camión los condujo a la Comisaría.

Pero véase en la Estrella del Mar la descripción de los incendios de la Flor y de Areneros. (A continuación vienen recortes de esta revista con el texto anteriormente citado). ${ }^{109}$

De Málaga se dice que sólo ha quedado sin profanar la Catedral y una parroquia. Las demás, sesenta y tantas, o quemadas o profanadas. El colegio se ha salvado del incendio. En Cádiz quemadas muchas iglesias, destrozadas las demás entre ellas nuestra casa y residencia. Lo mismo en Granada, Valencia, Alicante, Almería. ${ }^{110}$

Hoy han ingresado en la cárcel modelo varios de la Acción Nacional. Hemos estado con los Bustamantes en el Cerro de los Ángeles. Hay mucha concurrencia. Muchas personas de rodillas con los brazos en cruz; se reza y se cantan himnos sagrados. Es un milagro que esté en pie el monumento que simboliza la fe de España y la de sus reyes.

He visitado al P. Miguel de Alarcón; está inconsolable.

Día 14. Jueves. Sigue la inquina contra el venerable Primado que ha huido de España. ${ }^{111}$ Las calumnias y befas y caricaturas y sarcasmos contra la religión en los periódicos no tiene (sic) límite.

Decreto suprimiendo los empleos de Capitán General y Almirante de la Armada. No tengo nada de nuevo que apuntar, a no ser la noticia que cunde y que tiene todos los visos de verdad y de certidumbre. Que la quema de las casas religiosas se decretó en una junta habida en el Ateneo y que la lista de las casas que habían de ser quemadas la hicieron Fernando de los Ríos, ministro de Justicia, Marcelino Domingo ministro de Instrucción, Manuel Azaña ministro de la Guerra, otro ministro más que no he identificado, Ramón Franco, director de Aviación y Rada el mecánico del Plus Ultra. En la lista que allí se hizo se ponían las casas religiosas que había que quemar, pero las que allí no figuraban podían ser quemadas también si los incendiarios lo querían. En la lista figuraban también los depósitos

${ }^{104}$ Se está refiriendo a la imprenta de la Editorial del Apostolado de la Prensa.

105 Miguel Alarcón, pariente de los padres del mismo nombre, poetas y redactores del Mensajero del Sagrado Corazón de Jesús. Nacido en Madrid en 1873 morirá en Alcalá de Henares en 1960.

${ }^{106}$ El Padre Josè Panizo, nacido en Lima en 1877, era uno de los operarios jesuitas de la Calle de la Flor más activos y populares. Morirá en Madrid en 1956.

107 El Padre Francisco de Paula Sauras, nacido en Zaragoza, había ejercido en cargo de Maestro de Novicios hasta hacia poco. Morirá en Alcalá de Henares en 1962.

${ }^{108}$ El Padre Alfonso Torres era uno de los más famosos predicadores del momento. Tradicionalista de corazón, se exilió y vivió entre Biarritz y Roma, muy cerca del Cardenal Segura. Nacido en la localidad almeriense de Zurgena en 1879, moría en Granada en 1946.

${ }^{109}$ El texto está firmado por Luis Ortiz. La Estrella del Mar, 1931, pp 258-262.

${ }^{110}$ Ver nota 100.

${ }^{111}$ Cárcel Orti, V. 2011: 342-343. Carta de Segura a Pío XI. Lourdes, 14-5-1931. 
de gasolina de donde podían sustraerse especificando los sitios; la gasolina la dio la CAMPSA o sea el monopolio de petróleos que es una sociedad rusa soviética.

Hoy me han explicado la causa de porqué no se pudo incendiar el colegio nuestro de Chamartín; es la versión histórica, contada a mí mismo por el protagonista y detallada por testigos presenciales de los hechos. Hela aquí. El Colegio de Chamartín era el último que había de arder, por estar lejos del centro de Madrid. Después de destruir por completo el Colegio de las Maravillas y el convento contiguo de monjas, se encaminó la turba a Chamartín. De paso anotaré que en el convento de monjas (servitas o cosa así) penetraron en su cementerio, desenterraron los cadáveres, sacaron a la calle varias momias de religiosas, y después de varias profanaciones les echaban gasolina las quemaban. Anotaré también el caso de un infame que se brindó a salvar en un auto a una de las religiosas de 60 años, asegurándole que la llevaría a una casa muy honrada y la llevó a una casa de prostitución para violarla, cosa que impidieron compadecidas las mismas mujeres malas.

Llegó pues la turba a Chamartín, entre la cual se vió a Rada, mecánico del Plus Ultra y al alcalde de Madrid señor Rico y fue cuando yo salía con varios amigos hacia el Pinar. La guardia civil de la carretera les dejaba pasar impunemente. Llevaban gasolina abundante para quemar el colegio; pero vieron demasiado aparato de guardia civil y como estaba declarado ya el estado de guerra, temieron que se les impidiese el paso al colegio.

Entonces enviaron una comisión que sondease las órdenes que tuviera la Guardia civil y esperaron. El Colegio de las Madres del Sagrado Corazón se alza enfrente del nuestro a unos cien metros y el director de la salvaje comparsa preguntó que de quien era aquel edificio. Le respondieron que era un colegio de madres del Sagrado Corazón y el hombre miró la lista y dijo: Pues está en lista. Aquí está: Sagrado Corazón. Se equivocaba en ello, pues el que estaba en lista era el de las Esclavas del Sagrado Corazón, que está en la calle de Martínez Campos, pero eso de las Esclavas o solamente Madres del Sagrado Corazón no lo entendía él. Como la comisión que había ido a explorar la Guardia Civil tardaba, quiso aprovechar el tiempo y dio la orden de quemar el convento del Sagrado Corazón.

En este magnífico colegio, fundado por el duque de Pastrana, hay noviciado, juniorado y además internado de niñas, en total unas 300 mujeres. Llamó el capitán de los incendiarios a la puerta y anuncio que se iba a quemar el edificio pero que tenían órdenes de respetar las personas, que saliesen todas lo más aprisa posible. Dentro del colegio se desarrollaron escenas indescriptibles, pero que pregonan el valor y la serenidad de todas las monjas en especial de la vicaria la madre Carmen Modet?.

Acababan de terminar la bendición con el Santísimo cuando la madre Vicaria dio la orden de que se vistiesen rápidamente de seglares y saliesen con orden. Niñas internas había muy pocas. Se hizo así. Los mismos incendiarios les ayudaban a subir a los autos que se habían hecho venir para ellas. Se dio el caso de una madre, la sacristana creo que fue, que al salir se acordó de que aunque habían consumido las Sagradas Formas entre todas, pero la Forma grande del viril se había quedado en el sagrario. Se fue a la capilla; se encontró con que ya se había guardado la llave del sagrario. Buscó un hierro en la sacristía y forzó la puerta del sagrario y sacó la Sagrada Forma. La puerta del sagrario es de plata, llena por dentro de pedrería y obra de Granda, y la quiso salvar. Se la puso delante del pecho, la tapó y fingió estar jorobada y así salvó aquellos tesoros, uno de ellos de valor infinito.

Como la gasolina para quemar nuestro colegio la habían empleado en incendiar el de las madres, mandaron por más gasolina al puesto más cercano que tenían en lista, que estaba bien distante, y como había venido ya la comisión anunciando que la Guardia Civil tenía órdenes de dejarles hacer cuanto quisieran, quisieron aprovechar el tiempo mientras venía la gasolina en robar y destruir el interior del colegio, llevados de una creencia que entre ellos corría de que en el colegio se encontrarían dinero en abundancia. Entraron, pues, por delante de cien guardias civiles y comenzaron el saqueo hasta dejar el 
colegio en el estado que yo lo hallé al día siguiente. Según lo que me dijo un testigo presencial aquello no tiene nombre. Los colchones, los pianos, las máquinas de escribir, la ropa, los libros, todo lo echaban por las ventanas al jardín o a la carretera y, le prendían fuego y bailaban y hacía mil procacidades y es de notar que los más valientes en hacerlas eran niños de diez a catorce años.

Entró la turba como unos trescientos y entre ellos se mezclaron varios antiguos alumnos nuestros, disfrazados de obreros, con la intención de impedir lo que pudieran. Ellos guiaban grupos de turbas vociferando. Me contó uno de estos alumnos, cuyo nombre no recuerdo, que preguntó a otro amigo un tal Laborda:

- $\quad$ Oye, qué podemos salvar?

- $\quad$ Pues la biblioteca, el gabinete, y la Virgen del Recuerdo.

En efecto, en un papel puso uno de ellos en la puerta de la biblioteca (unos 40.000 volúmenes) este letrero que vi yo al día siguiente: "Ciudadanos, respetad esta sala, que es vuestra". No entró nadie en la Biblioteca. Otro de los supuestos incendiarios puso este letrero en la puerta del laboratorio de Química: "Camaradas, peligro de muerte. Fósforo y explosivos" y tampoco entraron. El texto de estos dos letreros no los recuerdo exactamente, pero poco más o menos decían lo que pongo aquí. Al penetrar en la capilla, después de profanar las imágenes, quisieron echar abajo la preciosa imagen de la Virgen del Recuerdo, patrona del Colegio, y dos de los disfrazados incendiarios se opusieron diciendo a gritos que aquella era imagen nacional de un mérito estupendo y soltó uno de ellos un bofetón a un mozalbete que había empezado a tirarle algunos cascotes. La imagen se salvo. Dentro estaban esperando la gasolina para rematar la obra cuando un suceso imprevisto salvó de las llamas el colegio. He aquí como me lo contó el protagonista Fernando ¿? Castejón, capitán de artillería, hijo de los Condes de Aibar, antiguo alumno de Chamartín. "Yo al saber que la turba se dirigía a Chamartín, temí por mi hermana, religiosa del Sagrado Corazón y me fui con mi automóvil a salvarla y a ver si podía hacer algo también por mi antiguo colegio de los jesuitas. Llegué a Chamartín cuando las turbas venían aún por la carretera, entré en el colegio de las madres y rogué a la madre Vicaria que me dejase llevar a mi hermana. La madre me dijo que según le habían asegurado la marejada no iba con ellas, pero que podía sacar a su hermana.

Yo la saqué y como viese que me seria imposible ya bajar al pueblo sin peligro de la vida, seguí por la carretera y fui al Noviciado de las MM Reparadoras, rogando a la Madre superiora que amparase a mi hermana. Esta la recibió (no pongo aquí lo que sufrieron las Madres reparadoras, porque la turba se encaminó al noviciado ya a boca de noche y la madre superiora tuvo que hacer salir a todas la madres y esperó con ellos en la carretera a las turbas; pero como ya la Guardia Civil había recibido órdenes de disparar, bastaron algunos disparos al aire para que la turba retrocediera carretera atrás y dejase en paz al convento de las monjas).

Después de dejar a mi hermana, retrocedí en el auto para ver lo que podía hacer en mi antiguo colegio de Chamartín y al pasar por delante del noviciado del Sagrado Corazón, ya éste era un horno de fuego. Me indigné, mandé al chauffeur que aligerase y me llevara a casa del Capitán General de Madrid Queipo de Llano para insultarle y protestar. Me encontré con el providencialmente en la calle del Cisne que disputaba con el general Orgaz al lado de su automóvil y me acerqué y yo no sé lo que le dije. El se quería excusar diciendo:

- $\quad$ Pero Castejón, ¿que voy a hacer? La turba es mucha, no se puede ir contra ella; no puedo hacer nada.

Chamartín.

¿Qué no? Déme permiso para tomar unos cuantos lanceros de mi compañía e ir a 
- Cójalos en buena hora. A bien que está declarado el estado de guerra, pero ya el colegio de los frailes jesuitas estará reducido a pavesas.

- $\quad$ Bien, eso lo veremos. Gracias, General. me dijo:

Entonces el general Orgaz que estaba también protestando de lo que estaba pasando en Madrid,

- Castejón, yo voy contigo. Veremos a ver si podemos hacer algo todavía.

Cogimos al paso tres taxis, llegamos al cuartel de lanceros; metimos en los taxis los que pudimos, creo que me dijo unos diez con lanzas y a todo correr de los autos llegamos a Chamartín. En el momento en que venía la gasolina pedida y comenzaban a rociar la portería.

Orgaz se encaró con el teniente de la Guardia civil y le gritó:

- ¿ ¿Qué pasa aquí? ¿Donde esta esa canalla?

- $\quad$ Dentro del Colegio, mi General.

- ¿Y porqué les has dejado entrar?

- $\quad$ Porque son las órdenes que tenemos.

- ¿ ¿Sí? Verá lo que hace con esas órdenes.

- $\quad$ Y seguido de los lanceros, revólver en mano, nos precipitamos dentro del colegio. El general Orgaz iba loco de ira, gritando: ¿Dónde están esos cobardes? ¿Dónde...? Y daba aullidos de rabia.

Entramos en la capilla. La turba estaba parodiando una misa. Un imbécil vestido ridículamente con ornamentos gritaba desde el altar mayor el prefacio. La gente le coreaba con blasfemias y palabras soeces, desde el coro aporreaban el ya destrozado armonium cantando. Al entrar nosotros, la turba se asustó, se dispersó como conejos por todos los tránsitos y hubo algunos que se tiraron por las ventanas del piso primero al jardín.

A los cinco minutos el interior del colegio estaba vacío y la turba del exterior había desaparecido sin realizar la obra del incendio.

Estos dos nombres del general Orgaz u del capitán González de Castejón deben ser escritos con letras de oro en los anales del Colegio de Chamartín.

Viernes 15 de Mayo. Voy dándome cuenta de los domicilios ocultos de los nuestros. He visitado algunos de ellos. Noto que el pesimismo se apodera de sus ánimas. Yo no he pasado ningún rato de desfallecimiento de ánimo. Presencio todo con cierta impresión de sublimidad. Es la obra de Dios. Nos merecemos lo que nos pasa: estamos muy apáticos y egoistones los católicos y nos conviene algún botón de fuego.

Siguen los encarcelamientos; siguen suspendidos El Debate y $A B C$ desde la noche del día 11. Por la noche me comunican la orden del P. Provincial de que me traslade a Loyola, donde ya hay bastantes padres y hermanos.

Sábado 16 de Mayo. Me traslado a casa de mi hermana, dejando la casa donde he estado oculto, la de don Felipe Bustamante. Es una casa de cuño genuinamente católico; se respeta la piedad y la austeridad cristiana en toda la numerosa familia. Compro algunas cosas y paso la noche en casa de mi hermana. Madrid está aparentemente tranquilo, pero le malestar, la pesadez de tormenta se masca. He visitado las ruinas de nuestra Casa profesa, del colegio de Areneros, del colegio de los Maravillas, de la 
iglesia de los Carmelitas de la Plaza de España. Todavía ayer por la tarde presencié una lucha entre las turbas saturadas en quemar el colegio de las Madres del Sagrado Corazón de Leganitos y un piquete de úsares que la defendía a todo trance. Era cosa digna de verse. En la desembocadura de la Gran Vía con la plaza de España está el colegio de las Madres haciendo esquina con la calle de la Princesa. En medio del transitar de la gente, veíase como por arte de magia a dispersos grupitos de dos o tres mozalbetes, que se estacionaban ante la tapia del colegio. Los úsares formaban dos alas a caballo con espadas desenvainadas y tercerolas. Al frente de cada ala un teniente a caballo y en el vértice de ambos un comandante. Al condensarse el núcleo, una de las alas de los úsares se echaba encima y los disolvía: un minuto después, ya estaban formando otro núcleo por la calle de la Princesa que volvía a dispersar la otra ala de úsares. Así estuvieron más de media hora, a las seis de la tarde, en plena luz, en medio de los transeúntes que pasaban como yo no nos divertíamos en ver aquel juego. Llegó por fin un camión con soldados y ametralladoras y un piquete de la guardia civil y se dispersaron los grupos.

Domingo 17 Mayo. Salgo en el rápido de Hendaya: me despide la familia de Bustamante y mi hermana. En mi departamento va también a San Sebastián don Camilo Torres, hermano del secretario particular del Rey, con su esposa y su hijo. Viaje tranquilo sin percance ninguno. Al llegar el policía secreto a registrar documentos, le digo en voz baja que soy jesuita, aunque vestido de traje seglar. Me dice amablemente que no tenga cuidado. Tienen órdenes de dejarnos pasar al Norte y atravesar si queremos la frontera. Llegó a Loyola por la noche. Aquí me encuentro con bastantes padres. Los novicios de Aranjuez, etc".

FIN

\section{BIBLIOGRAFIA}

Alba, S. 1931. "Por España, con la República”. El Imparcial, Madrid, 19-5-1931.

Almagro de San Martín, M. 1947. Ocaso y fin de un reinado. Alfonso XIII. Los reyes en el destierro: Madrid.

Armiñan, L. 1984. Sánchez Guerra: Madrid.

Arrarás, J. 1964. Historia de la Segunda República española: tomo I: Madrid: Editora Nacional

Azpiroz, J. M. y Broto, F. 1984. La sublevación de Jaca: Zaragoza.

Ben-Ami, Sh. 1990. Los orígenes de la Segunda República: anatomía de una transición: Madrid

Berenguer y Fusté, D. 1946. De la Dictadura a la República. Crisis del reinado de Alfonso XIII: Madrid.

Bravo Morata, F. 1973. De la dictadura a la República, 1930-1931: Madrid.

Caballero, J. 1977. Corazón de España. Historia del monumento del Cerro de los Ángeles, 1900-1976: Madrid: Fe Católica.

Calvo, R. 1931. Labor de los jesuitas españoles: Valladolid

Cárcel Ortí, V. 2011. La II República y la Guerra Civil en el Archivo Secreto Vaticano. 1.1. Documentos del año 1931. Febrero-julio: Madrid: Biblioteca de Autores Cristianos.

Carlavilla, M. 1956. El Rey. Radiografia del reinado de Alfonso XIII: Madrid. 
Carreras de, F. 1983. "Los intentos de reforma electoral en la segunda república": Revista de Estudios Políticos: 165-197.

Christian JR, W. A. 2011. El reinado de Cristo en la Segunda República. Una historia silenciada: Barcelona: Ariel

Comín Colomer, E. 1956. Jaca: Madrid.

Comín Colomer, E. 1967. Historia del Partido Comunista de España: Madrid: Editora Nacional.

Cruz Martínez, R. 1987. El Partido Comunista de España en la segunda república: Madrid

De la Cierva Peñafiel, J. 1955. Notas de mi vida: Madrid.

De la Serna, V. 1932. "Clérigos y abogados": La Voz, Madrid, 17-6-1932.

De Luis Martín, F. y Arias González, L. 1997. Las Casas del Pueblo socialista en España (19001936): estructura social y arquitectónica: Barcelona.

Domínguez Niñas, J. L. 1990. "La implantación comunista en el primer bienio republicano". Anales del Instituto de Estudios Madrileños, 28: 495-514.

Echeverría, T. 1966. Sobre la caída de Alfonso XIII. Errores y ligerezas del propio rey que influyeron en su destronamiento: Sevilla.

Fernández Flórez, W. 1931. "Los futuros ministros”, $A B C$ : Madrid, 17-6-1932.

Figueroa y Torres, A. 1947. Notas de mi vida, 1912-1931: Madrid: Espasa-Calpe

Figueroa y Torres, A. 1947. Y sucedió así: Aportación para la historia: Madrid

Freira Suárez, F. 1997. Ramón Pérez de Ayala: testigo de su tiempo: Gijón.

Galindo Herrero, S. 1953. El 14 de abril: Madrid

García Venero, M. 1954. Melquiades Álvarez. Historia de un Liberal: Madrid.

Garriga Alemany, R. 1978. Ramón Franco, el hermano maldito: Barcelona.

Gibson, I. 1986. Queipo de Llano. Sevilla, verano de 1936: Barcelona.

Gil Delgado, F. 2001. Pedro Segura: un cardenal de Fronteras: Madrid: Biblioteca de Autores Cristianos.

Gil Pecharromán, J. 1994. Conservadores subversivos. La derecha autoritaria en España (1900-1936): Madrid: Eudema.

Gómez Molleda, Ma . D. 1986. La masonería en la crisis española del siglo XX: Madrid.

Gómez Navarro, J. L. 1991. El régimen de Primo de Rivera. Reyes, dictaduras y dictadores: Madrid

Gómez Santos, M. 1964. La reina Victoria Eugenia de cerca: Madrid

González Calleja, E. y Souto Kustrin, S. 2007. "De la Dictadura a la República: Orígenes y auge de los movimientos juveniles en España". Hispania: 225

Gutiérrez Vega, Z. 2001. Victoria Kent: una vida al servicio del humanismo liberal: Málaga.

Hernández Figueiredo, J. R., 2003. "Anticlericalismo incendiario en el comienzo de la II República española (11-13 de mayo de 1931), a la luz de los informes inéditos vaticanos. Antologia Annua: 50: $243-310$ 
Hernández Figueiredo, J. R., 2010. “Avances y estado del comunismo en vísperas de la guerra civil española”. Analecta sacra tarraconensia 83: 759-906.

Iribarren, J. M. 1945. El general Mola: Madrid.

Jato Miranda, D. 1976. Madrid capital republicana: Madrid

Jiménez de Asúa, L. 1931. Nueva especie de señorito, en La Libertad, Madrid 7-8-1931.

Jiménez de Asúa, L. 1931. "Un pueblo ejemplar”. La Libertad. Madrid, 13-5-1931.

Juliá, S. 1984. Madrid, 1931-1934. De la fiesta popular a la lucha de clases: Madrid: Siglo XXI.

Laín Entralgo, P. 1969. Gregorio Marañón. Vida, obra y persona: Madrid

López Ochoa, E. 1930. De la Dictadura a la República: Madrid.

López Vega, A. 2011. Gregorio Marañón. Radiografia de un liberal: Madrid.

Luca de Tena, J. I. 1975. Papeles para la pequeña y la gran historia. Memorias de mi padre y mías: Barcelona.

Luca de Tena, J. I. 1991. Mis amigos muertos: Barcelona.

Mantilla, S. 1930. Un jesuita en las minas. El padre Juan Manuel de Obeso en la zona minera de Vizcaya: Valladolid.

Marañón, G. 1931. “La monarquía ha muerto de enquistamiento. Comentario primero". El Sol, Madrid 21-5-1931.

Marañón, G. 1931. “El problema religioso. La sugestión del mito”, El Sol: Madrid, 13-11-1931.

Marín, C. 1933. Círculo Católico de Obreros de Burgos. Cincuenta años de Acción Social Católica: Burgos

Marina, M. 1936. “La última lección. Comentario editorial”. Razón y Fe: 433-451

Martínez Sánchez, S. 2004. Los papeles perdidos del Cardenal Segura (1880-1957): Pamplona: EUNSA.

Martorell Linares, M. 2011. José Sánchez Guerra (1859-1935). Un hombre de honor: Madrid.

Maura, M. 1962. Así cayó Alfonso XIII: Madrid.

Maura, M. 2007. Y así cayó Alfonso XIII. De una dictadura a otra: Madrid

Maurín, J. 1932. La revolución española. De la monarquía absoluta a la revolución socialista: Madrid.

Nadal Sánchez, A. 1986. La República en Málaga: Diputación Provincial.

Narbona, F. 1954. La quema de los conventos: Madrid: Publicaciones Españolas

Olmedo Delgado, A. 1958. General Queipo de Llano (aventura y audacia): Barcelona.

Pérez de Ayala, R. 1931. “Las mujeres harán la nueva España”. El Socialista. Madrid, 18-7-1931.

Plá, J. 1986. Madrid, el advenimiento de la República: Madrid: Alianza.

Plá, J. 2006. La Segunda República Española. Una crónica (1931-1936): Barcelona: Destino.

Radcliff, P. B., 2004. De la movilización a la Guerra Civil: historia social y política de Gijón (19001936): Barcelona: Debate. 
Ranzato, G. 2006. El eclipse de la democracia. La Guerra Civil española y sus orígenes, 1931-1939: Madrid: Siglo XXI.

Revuelta González, M. 1984 y 1991. La Compañía de Jesús en la España Contemporánea: Madrid: Universidad Pontificia Comillas.

Robinson, R. A. H. 1974. Los orígenes de la España de Franco. Derecha, República y Revolución (1931-1936): Barcelona: Grijalbo.

Ruiz Salvador, A. 1976. Ateneo, dictadura, república: Valencia: Fernando Torres.

Sánchez Maurandi, A. 1962. Juan de la Cierva. Estudio biográfico del político murciano: Murcia

Sanz de Diego, R. Ma. 2009. ICAI: 1908-2008: lo que fuimos, lo que somos: Madrid: Universidad Pontificia Comillas.

Seco Serrano, C. 1979. Alfonso XIII y la crisis de la restauración: Madrid: Rialp

Soldevilla Zubiburo, F. 1977. Història de la proclamació de la república a Catalunya: Barcelona

Tusell Gómez, J. 1970. La segunda republica en Madrid: elecciones y partidos politicos: Madrid

Vallotton, H. 1943. Alfhonse XIII: Lausanne.

Verdoy, A. 1995. Los bienes de los jesuitas. Disolución e incautación de la Compañía de Jesús durante la Segunda República: Madrid: Trotta.

Verdoy, A. 2010. "La Confederación Nacional Española de las Congregaciones Marianas o la movilización de la juventud de la Virgen (1919-1923)". Estudios Eclesiásticos (85): 547-573

Vigón, J. 1957. General Mola, el Conspirador: Barcelona.

Villalaín García, P. 1987. Las elecciones municipales de 1931 en Madrid: Madrid

Zabala, J. M. 2009. Franco, el republicano: la vida secreta de Ramón Franco el hermano maldito del caudillo: Barcelona

Zapatero, V. 1999. Fernando de los Ríos: biografía intelectual: Granada-Valencia: Pre-TextosDiputación de Granada.

Zorrilla Bonilla, J. 2010. "Discursos irresponsables y retóricas intransigentes", en D. Del Río (ed), Palabras como puños. La intransigencia política en la Segunda República española, 523-595: Madrid: Taurus. 